\title{
The Bjergebakke dyke - a kullaite from Bornholm
}

\author{
AAGE JENSEN
}

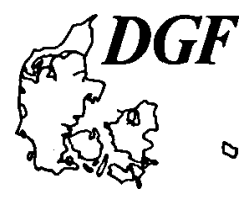

Jensen, Aa.: The Bjergebakke dyke - a kullaite from Bornholm. Bull.geol.Soc.Denmark, Vol. 37, pp. 123-140, Copenhagen, April 10th, 1989. https://doi.org/10.37570/bgsd-1988-37-11

The Bjergebakke dyke is a 2-3 m wide dyke trending northwest and cutting through the Almindingen granite in the central part of Bornholm.

Along the contáct there is an approximately $1 \mathrm{~cm}$ thick white zone consisting almost exclusively of albite, and the dyke has suffered from later autometasomatic alteration, mainly albitisation.

The dyke consists of feldspar, albite as well as potassium feldspar, chlorite, mica and opaque minerals, mainly titanomagnetite, beside traces of calcite and amphibole.

The composition of the feldspars, chlorite, mica and titanomagnetite have been determined by electron microprobe analysis.

Whole rock analyses, major elements as well as trace elements were carried out in two profiles across the dyke with sample distances of 30 and $25 \mathrm{~cm}$ respectively.

It is concluded that the present distribution of elements is due to autometasomatic alteration and that any original magmatic differentiation can no longer be seen.

Both the direction of and the mineralogical and chemical composition of the Bjergebakke dyke is quite similar to that of the kullaites in Scania, but whereas the dykes in the Precambrian of Bornholm are considered to be Precambrian, the kullaites have been considered post-Silurian.

Age determinations of these rocks are being undertaken.

Aage Jensen, Institute of Mineralogy, University of Copenhagen, Øster Voldgade 10, DK-1350 Copenhagen K, Denmark, Februar 24th, 1988.

\section{Introduction}

The Precambrian of Bornholm covers the northernmost three quarters of the island and consists mainly of granites and gneisses. These rocks are cut by several dolerite dykes trending between north and northeast. However, in the quarry at Bjergebakke (fig. 1) a 2 to $3 \mathrm{~m}$ wide dyke trending northwest $\left(130^{\circ} / 88^{\circ} \mathrm{SW}\right)$ occurs; this dyke is not of doleritic composition, but has a composition quite similar to the kullaite dykes in Scania.

The Bjergebakke dyke is strongly altered by autometasomatism, but nevertheless its similarity with the kullaite dykes has warranted a closer study. The Bjergebakke dyke has the same trend and the same mineralogical and chemical composition as the kullaites, but whereas the kullaites are considered to be post-Silurian (Hjelmqvist 1930), all dykes on Bornholm are usually considered to be Precambrian, because they are never seen cutting the Eocambrian and Lower Palaeozoic sediments occurring south of the Precambrian of this island.

The Bjergebakke quarry is situated just north of the road between Rønne and Svaneke $9 \mathrm{~km}$ east of Rønne. In the quarry the dyke can be followed over a distance of $100 \mathrm{~m}$. The width of the dyke varies from $3 \mathrm{~m}$ in the southeastem part to $2 \mathrm{~m}$ in the northwestern part.

On the northwestern wall of the quarry an only $5 \mathrm{~cm}$ thick veinlet is seen about $50 \mathrm{~cm}$ west of the

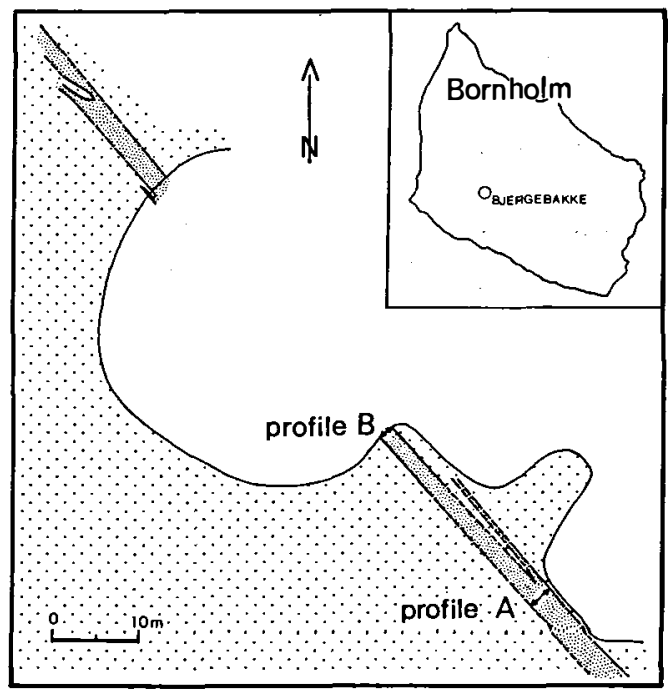

Fig. 1. Sketch map of the Bjergebakke quarry 
Table 1. Average modal composition of the two profiles in volume percentages

\begin{tabular}{lrc}
\hline & A-profile & B-profile \\
\hline Feldspar & $51.4 \pm 2.9$ & $51.2 \pm 3.7$ \\
Chlorite & $35.1 \pm 3.3$ & $32.3 \pm 6.3$ \\
Mica & $4.9 \pm 1.7$ & $7.6 \pm 4.3$ \\
Opaque minerals & $4.6 \pm 0.8$ & $4.7 \pm 0.6$ \\
Apatite & $1.8 \pm 0.8$ & $3.3 \pm 0.4$ \\
Calcite & tr. & tr. \\
Epidote & $2.2 \pm 0.7$ & $0.7 \pm 0.7$ \\
Titanite & $0.1 \pm 0.1$ & $0.4 \pm 0.1$ \\
\hline
\end{tabular}

main dyke. The veinlet continues into the wall but thins out and after $80 \mathrm{~cm}$ it vanishes. Digging in the bottom of the quarry has shown that this veinlet is connected to the main dyke. Splitting-up of the dyke can also be observed in the southeastern part where a $50 \mathrm{~cm}$ thick vein can be followed for about $15 \mathrm{~m}$.

The Bjergebakke dyke cuts through the Almindingen granite which constitutes the main part of the quarry. Along the contacts between dyke and granite the dyke margin is frequently developed as an approximately $1 \mathrm{~cm}$ thick white zone of alteration.

\section{Sampling}

Samples were collected from two profiles across the dyke (fig. 1). The A-profile is $3 \mathrm{~m}$ wide and samples were taken from both contacts inwards with a distance of $30 \mathrm{~cm}$ between samples, except that $60 \mathrm{~cm}$ from the $S W$ contact no sample could be obtained because of lack of exposure. In the B-profile the dyke is $2 \mathrm{~m}$ wide and samples were taken from both contacts inwards with a sample interval of $25 \mathrm{~cm}$. In the laboratory the two contact samples of the B-profile were each split in two, one representing $0-3 \mathrm{~cm}$ from the contact, the other representing $3-6 \mathrm{~cm}$ from the contact. The $5 \mathrm{~cm}$ veinlet were sampled in full width.

In order to see to what extent the dyke intrusion with its white border zone of alteration had influenced the country rock, the granite country rock was also sampled. Samples were taken from the NW wall as well as the $\mathrm{SW}$ wall of the quarry at distances of $5 \mathrm{~cm}, 50 \mathrm{~cm}, 3 \mathrm{~m}$ and 16 $\mathrm{m}$ from the contact respectively.

\section{Sample description}

The contact samples are dense grey with phenocrysts of feldspar about $1 \mathrm{~mm}$ in length and miarolitic cavities up to $2 \mathrm{~mm}$ in diameter. The sample from the NE contact of the B-profile contains a few discontinuous streaks about $0.1 \mathrm{~mm}$ thick of pyrite.

The remaining samples are all fine-grained and grey. The grain-size increases from the contacts inwards until $60 \mathrm{~cm}$ from the contact in the Aprofile and until $50 \mathrm{~cm}$ in the B-profile, after which the grain size remains constant. The samples have reddish spots consisting of clusters of feldspar in glomeroporphyritic aggregates, frequently having miarolitic cavities more or less filled with chlorite. The size of the glomeroporphyritic aggregates is generally $2-3 \mathrm{~mm}$, but in the B-profile they occasionally reach $10 \mathrm{~mm}$. The size of the miarolitic cavities varies from less than $1 \mathrm{~mm}$ to about $2 \mathrm{~mm}$.

The contact samples have trachytic texture, in the other samples the texture is trachytic to intersertal.

The $5 \mathrm{~cm}$ veinlet is dense black with phenocrysts of feldspar up to $1 \mathrm{~mm}$ in length and miarolitic cavities less than $1 \mathrm{~mm}$; the texture is trachytic.

The granite samples are medium-grained reddish grey and without visible differences; the texture is best described as equigranular, although some of the feldspar grains are up to $1 \mathrm{~cm}$ in diameter.

\section{Mineralogical composition}

Modal compositions have been determined by point counting of at least 1500 points in each sample; the contact samples, however, have too small a grain-size to allow point counting. For the samples of the B-profile and one of the samples of the A-profile $(120 \mathrm{~cm}$ from the $S W$ contact), 1500 points have been counted in each of two different thin sections.

The average composition of the two profiles are rather similar (table 1). Calcite is found only in the samples nearest to the contacts, and in the sample $25 \mathrm{~cm}$ from the SW contact of the Bprofile some grains of amphibole is encountered.

The main difference between the two profiles 
Fig. 2. Variations across the dyke of the main minerals
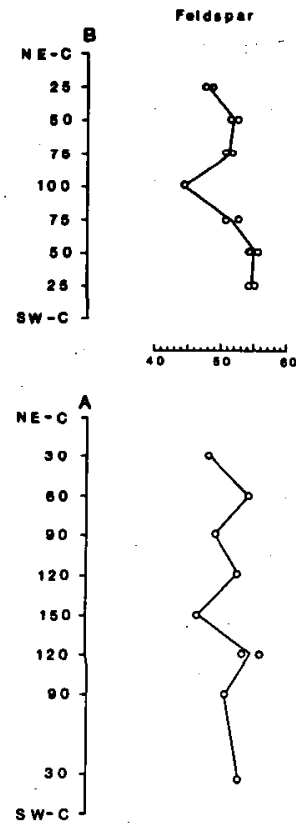

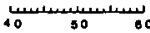
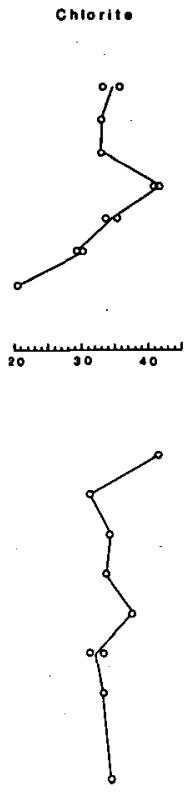

20

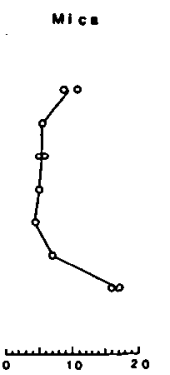

ore
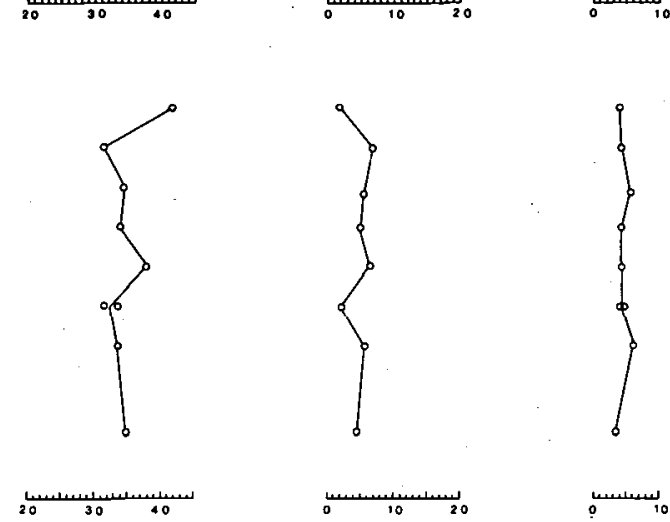

is that the B-profile is richer in mica and poorer in chlorite than the A-profile.

As regards variations across the dyke, correspondence between the two profiles is rather poor. Fig. 2 shows the variation across the dyke in the content of main minerals (apatite, epidote, titanite and calcite are omitted). (Where in the B-profile and at $120 \mathrm{~cm}$ from the $\mathrm{SW}$ contact of the A-profile only one point (circle) is shown, the counts for the two different thin sections are identical).

In the B-profile the feldspar content decreases from the SW contact inwards towards the middle of the dyke where there is a minimum. From the middle towards the NE contact feldspar increases until $50 \mathrm{~cm}$ from the contact and then decreases against the contact. In the A-profile the amount of feldspar fluctuates, but the minimum in the middle of the dyke can be recognized.

In the B-profile chlorite increases rapidly from the SW contact towards the middle where there is a maximum; near the NE contact there seems to be again a slight increase. In the A-profile the maximum in the middle can be recognized, but chlorite decreases inwards in the contact zone.

In the B-profile mica decreases abruptly from both contacts inwards. In the A-profile mica fluctuates but increases from both contacts inwards.
It is the difference between the two profiles in behaviour of chlorite and mica that causes the difference in average composition.

Opaque minerals show a slight increase from both contacts inwards in both profiles, but whereas the B-profile has a maximum in the middle of the dyke, the trend in the A-profile changes so that there is a low in the middle.

\section{Feldspar}

Feldspar laths constitute about half of the rock and give rise to a trachytic texture at and near the contacts. In the interior of the dyke the texture varies between trachytic and intersertal.

Average size of the feldspar laths is about $0.15 \times 0.75 \mathrm{~mm}$, except at the actual contacts where the average size of feldspar laths is $15 \times 75$ $\mu \mathrm{m}$, but phenocrysts up to $0.15 \times 0.75 \mathrm{~mm}$ are also present at the contacts.

The feldspar is not fresh, being strongly altered to sericite and epidote, and it is not possible in the microscope to distinguish plagioclase from potassium feldspar. Electron microprobe analyses have however proved the presence of potas. sium feldspar as well as albite. These two minerals are generally intimately intergrown. The back 


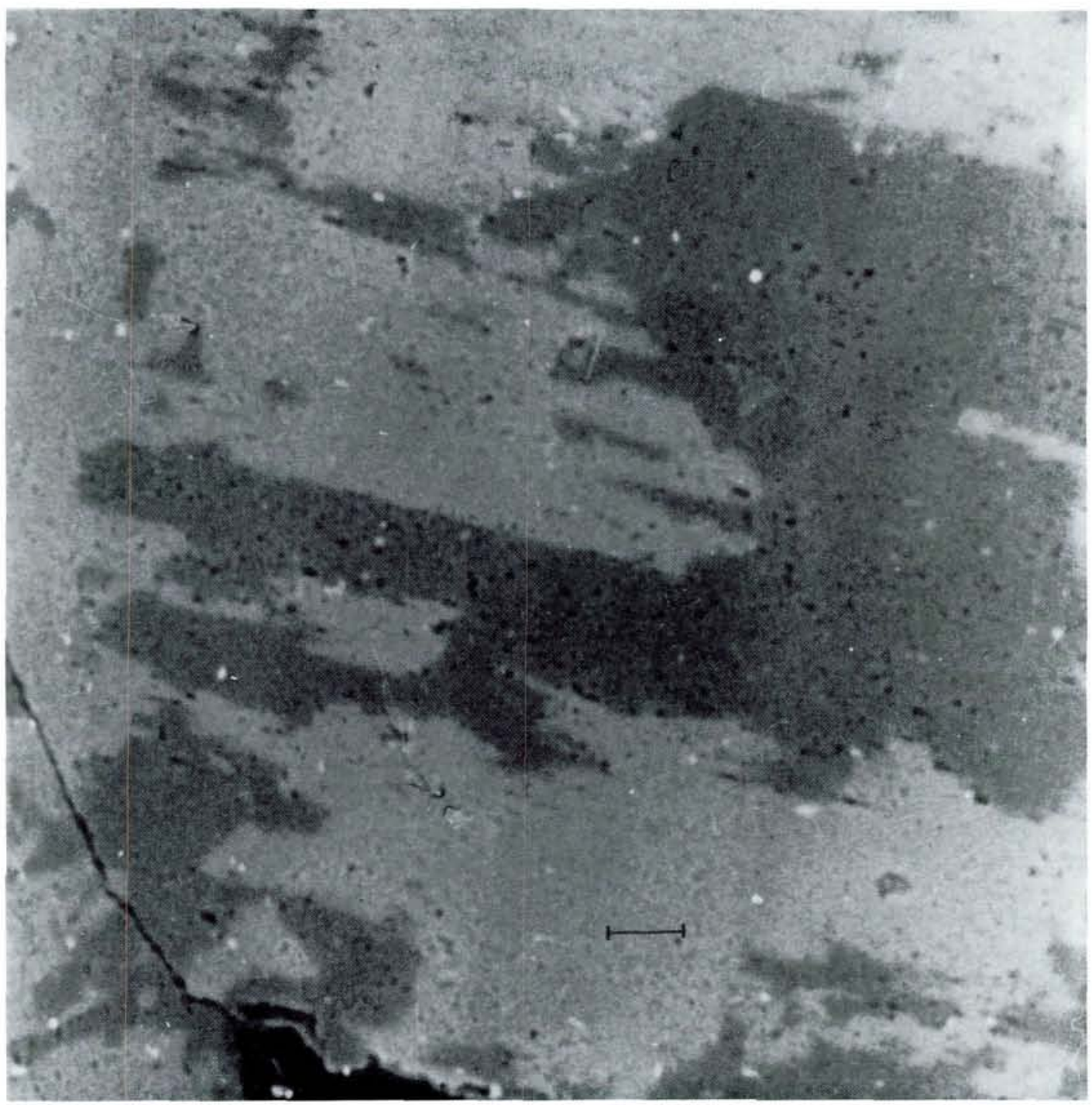

Fig. 3. Photo of the back scatter electron image of the microprobe. Dark grey albite, light grey potassium feldspar. Scale bar is $5 \mu \mathrm{m}$

scatter electron image of the microprobe can distinguish potassium feldspar from albite, as the latter is somewhat darker than potassium feldspar. Fig. 3 shows the intimate intergrowth of these two minerals.

Electron microprobe analyses of feldspar have been carried out on the samples of the B-profile from the SW contact to the centre and also on the sample of the $5 \mathrm{~cm}$ veinlet. In this sample and in the contact sample, however, all attempts to analyse what appears to be potassium feldspar have resulted in sericite analyses. The results of the electron microprobe analyses are shown in table 2 for albite and table 3 for potassium feldspar.

It can be seen from the tables that the variation between different grains in the same sample are as large as the variation in feldspars from different samples across the dyke, so no variation across the dyke can be established for either albite or potassium feldspar.

The average of the 34 albite analyses is $\mathrm{Ab} 95.1$ \pm 1.9 An $3.8 \pm 1.8$ Or $1.1 \pm 0.9$, and the average of the 14 analyses of potassium feldspar is Or 95.9 $\pm 1.9 \mathrm{Ab} 3.6 \pm 1.8 \mathrm{An} 0.6 \pm 0.6$. 
Table 2. Plagioclase analyses

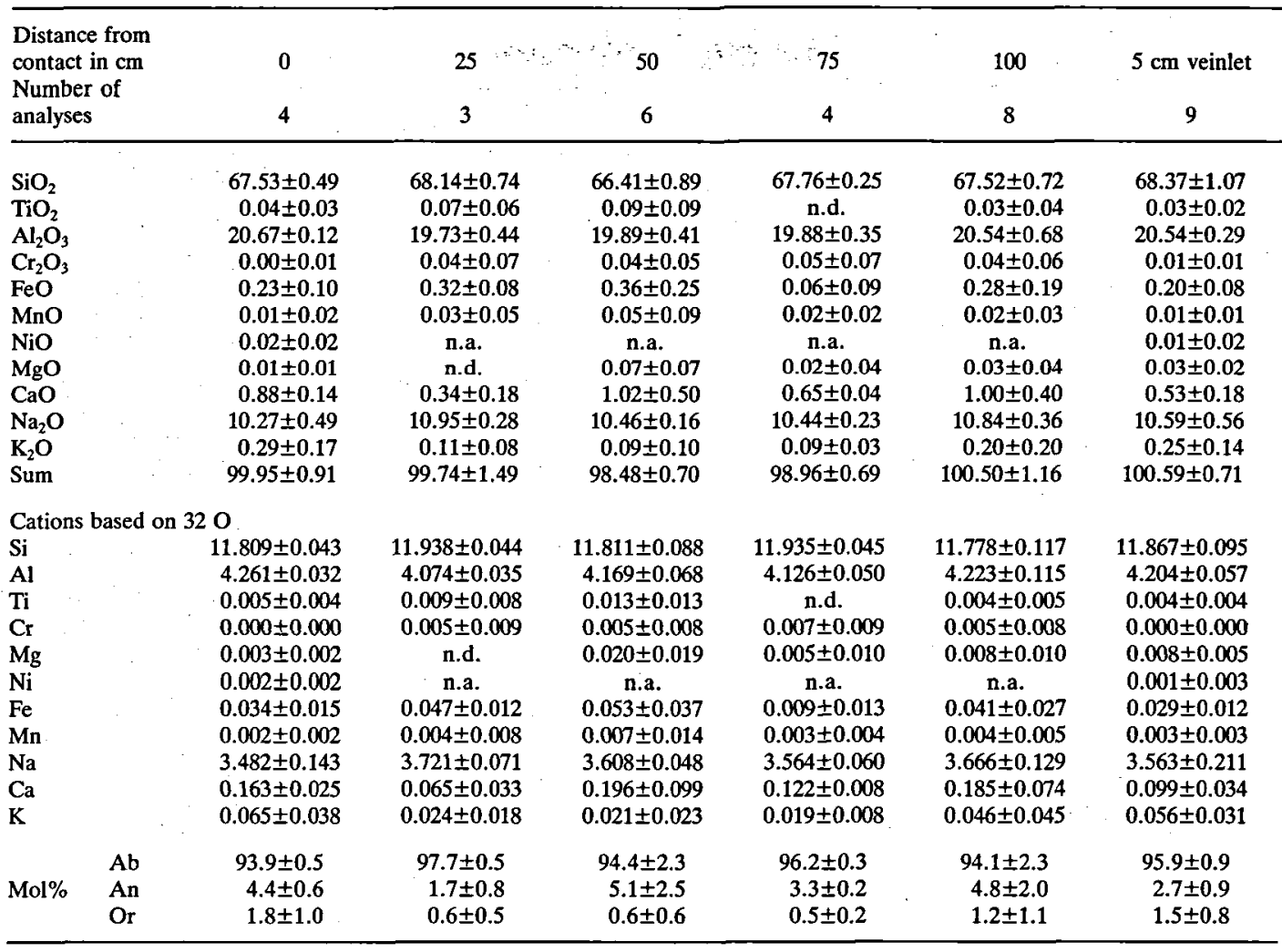

n.d. not detected

n.a. not analysed for

The electron microprobe analyses of the feldspar as well as of the chlorite, mica, amphibole and titanomagnetite were carried out with a Jeol Superprobe JCXA 733 with $15.0 \mathrm{kV}$ accelerating voltage and a sample current of $20.0 \mathrm{nA}$ using albite, hematite, wollastonite, potassium feldspar, $\mathrm{MgO}, \mathrm{Al}_{2} \mathrm{O}_{3}, \mathrm{TiO}_{2}, \mathrm{Cr}, \mathrm{Mn}$ and $\mathrm{Ni}$ as standards. In the analyses of titanomagnetite total iron was divided betwen ferrous and ferric iron by the method suggested by Finger (1972).

The $1 \mathrm{~cm}$ thick white zone of alteration at the border of the dyke

$\mathrm{X}$-ray investigation by the Guinier method (E.Leonardsen, Institute of Mineralogy, University of Copenhagen) has revealed that this altered material has a grain size about $1 \mu \mathrm{m}$ and the only crystalline phase visible on the Guinier film is a plagioclase very near to albite.

A chemical analysis carried out by the Geolog- ical Survey of Greenland, where $\mathrm{SiO}_{2}, \mathrm{Al}_{2} \mathrm{O}_{3}$, $\mathrm{CaO}, \mathrm{K}_{2} \mathrm{O}, \mathrm{MgO}, \mathrm{MnO}, \mathrm{Fe}_{2} \mathrm{O}_{3}, \mathrm{TiO}_{2}$ and $\mathrm{P}_{2} \mathrm{O}_{5}$ were determined by X-ray fluorescence (I.Sørensen) and $\mathrm{Na}_{2} \mathrm{O}$ by atomic absorption (J.Kystol), sums up to only $97 \%$ and shows a high content of $\mathrm{TiO}_{2}(1.98 \%)$, which is not consistent with plagioclase being the only phase present. According to the Guinier investigation this $\mathrm{TiO}_{2}$ must be either amorphous or below the detection limit.

If only the contents of $\mathrm{Na}_{2} \mathrm{O}, \mathrm{CaO}$ and $\mathrm{K}_{2} \mathrm{O}$ are taken into consideration, the analysis gives a plagioclase with the composition Ab 87.9 An 10.6 Or 1.5 in mole percentages, which is somewhat more calcic than the plagioclase in the dyke proper.

\section{Chlorite}

Next to feldspar chlorite is the most abundant mineral in the Bjergebakke dyke. The chlorite is 
Table 3. Potassium feldspar analyses

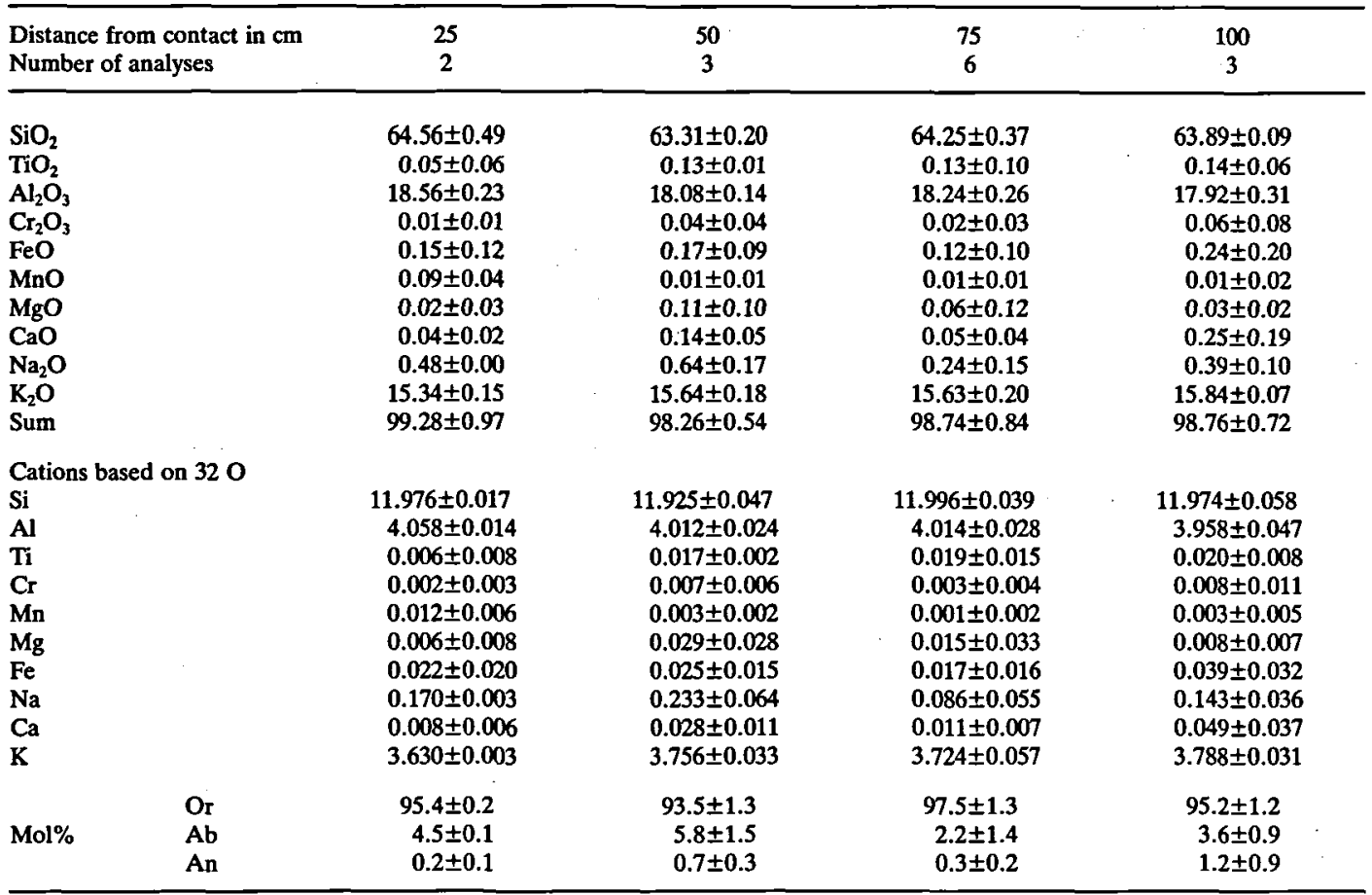

Table 4. Chlorite analyses

\begin{tabular}{|c|c|c|c|c|c|}
\hline $\begin{array}{l}\text { Distance from contact in } \mathrm{cm} \\
\text { Number of analyses }\end{array}$ & $\begin{array}{l}0 \\
6\end{array}$ & $\begin{array}{c}25 \\
5\end{array}$ & $\begin{array}{l}50 \\
10\end{array}$ & $\begin{array}{c}75 \\
8\end{array}$ & $\begin{array}{c}100 \\
8\end{array}$ \\
\hline $\begin{array}{l}\mathrm{SiO}_{2} \\
\mathrm{TiO}_{2} \\
\mathrm{Al}_{2} \mathrm{O}_{3} \\
\mathrm{Cr}_{2} \mathrm{O}_{3} \\
\mathrm{FeO} \\
\mathrm{MnO} \\
\mathrm{NiO} \\
\mathrm{MgO} \\
\mathrm{CaO} \\
\mathrm{Na}_{2} \mathrm{O} \\
\mathrm{K}_{2} \mathrm{O} \\
\mathrm{Sum}\end{array}$ & $\begin{array}{r}26.56 \pm 0.47 \\
0.04 \pm 0.02 \\
16.95 \pm 0.22 \\
0.02 \pm 0.02 \\
32.77 \pm 0.69 \\
0.69 \pm 0.03 \\
0.01 \pm 0.02 \\
8.38 \pm 0.30 \\
0.22 \pm 0.05 \\
0.00 \pm 0.01 \\
0.09 \pm 0.07 \\
85.73 \pm 0.69\end{array}$ & $\begin{array}{r}27.69 \pm 0.97 \\
0.08 \pm 0.05 \\
16.29 \pm 0.58 \\
0.00 \pm 0.01 \\
33.40 \pm 2.97 \\
0.82 \pm 0.12 \\
\text { n.a. } \\
9.87 \pm 1.88 \\
0.31 \pm 0.13 \\
0.30 \pm 0.18 \\
0.16 \pm 0.03 \\
88.94 \pm 0.53\end{array}$ & $\begin{array}{r}27.17 \pm 0.99 \\
0.04 \pm 0.06 \\
16.99 \pm 1.55 \\
0.03 \pm 0.05 \\
31.24 \pm 1.95 \\
0.68 \pm 0.18 \\
\text { n.a. } \\
10.63 \pm 1.93 \\
0.22 \pm 0.08 \\
0.59 \pm 0.20 \\
0.04 \pm 0.03 \\
87.62 \pm 0.68\end{array}$ & $\begin{array}{r}27.49 \pm 0.78 \\
0.02 \pm 0.03 \\
17.18 \pm 1.46 \\
0.09 \pm 0.06 \\
31.29 \pm 1.75 \\
0.72 \pm 0.26 \\
\text { n.a. } \\
11.13 \pm 1.72 \\
0.12 \pm 0.06 \\
0.17 \pm 0.17 \\
0.10 \pm 0.07 \\
88.29 \pm 1.06\end{array}$ & $\begin{array}{r}28.70 \pm 0.55 \\
0.53 \pm 0.85 \\
15.86 \pm 0.70 \\
0.02 \pm 0.04 \\
32.17 \pm 1.55 \\
0.53 \pm 0.12 \\
\text { n.a. } \\
10.65 \pm 1.11 \\
0.20 \pm 0.07 \\
0.13 \pm 0.12 \\
0.56 \pm 0.96 \\
89.36 \pm 1.37\end{array}$ \\
\hline $\begin{array}{l}\text { Cations per half unit cell bas } \\
\mathrm{Si} \\
\mathrm{Al}^{\mathrm{IV}} \\
\mathrm{Al}^{\mathrm{VI}} \\
\mathrm{Fe} \\
\mathrm{Mn} \\
\mathrm{Mg}\end{array}$ & $\begin{array}{l}\text { on } 140 \\
3.00 \pm 0.05 \\
1.00 \pm 0.05 \\
1.26 \pm 0.04 \\
3.10 \pm 0.06 \\
0.07 \pm 0.01 \\
1.41 \pm 0.04\end{array}$ & $\begin{array}{l}3.02 \pm 0.07 \\
0.98 \pm 0.07 \\
1.11 \pm 0.04 \\
3.05 \pm 0.31 \\
0.08 \pm 0.01 \\
1.60 \pm 0.29\end{array}$ & $\begin{array}{l}2.98 \pm 0.10 \\
1.02 \pm 0.10 \\
1.17 \pm 0.12 \\
2.86 \pm 0.20 \\
0.06 \pm 0.02 \\
1.73 \pm 0.30\end{array}$ & $\begin{array}{l}2.98 \pm 0.10 \\
1.02 \pm 0.10 \\
1.17 \pm 0.08 \\
2.84 \pm 0.19 \\
0.07 \pm 0.02 \\
1.80 \pm 0.25\end{array}$ & $\begin{array}{l}3.09 \pm 0.05 \\
0.91 \pm 0.05 \\
1.10 \pm 0.05 \\
2.89 \pm 0.13 \\
0.05 \pm 0.01 \\
1.71 \pm 0.18\end{array}$ \\
\hline $\begin{array}{l}\text { Sum }^{\mathrm{V}} \\
\mathrm{Fe} / \mathrm{Fe}+\mathrm{Mg}\end{array}$ & $\begin{array}{c}5.83 \pm 0.05 \\
0.687 \pm 0.072\end{array}$ & $\begin{array}{c}5.84 \pm 0.05 \\
0.655 \pm 0.063\end{array}$ & $\begin{array}{c}5.83 \pm 0.04 \\
0.624 \pm 0.059\end{array}$ & $\begin{array}{c}5.87 \pm 0.05 \\
0.613 \pm 0.050\end{array}$ & $\begin{array}{c}5.75 \pm 0.21 \\
0.629 \pm 0.026\end{array}$ \\
\hline
\end{tabular}

n.a. not analysed for 
Table 5. Mica analyses

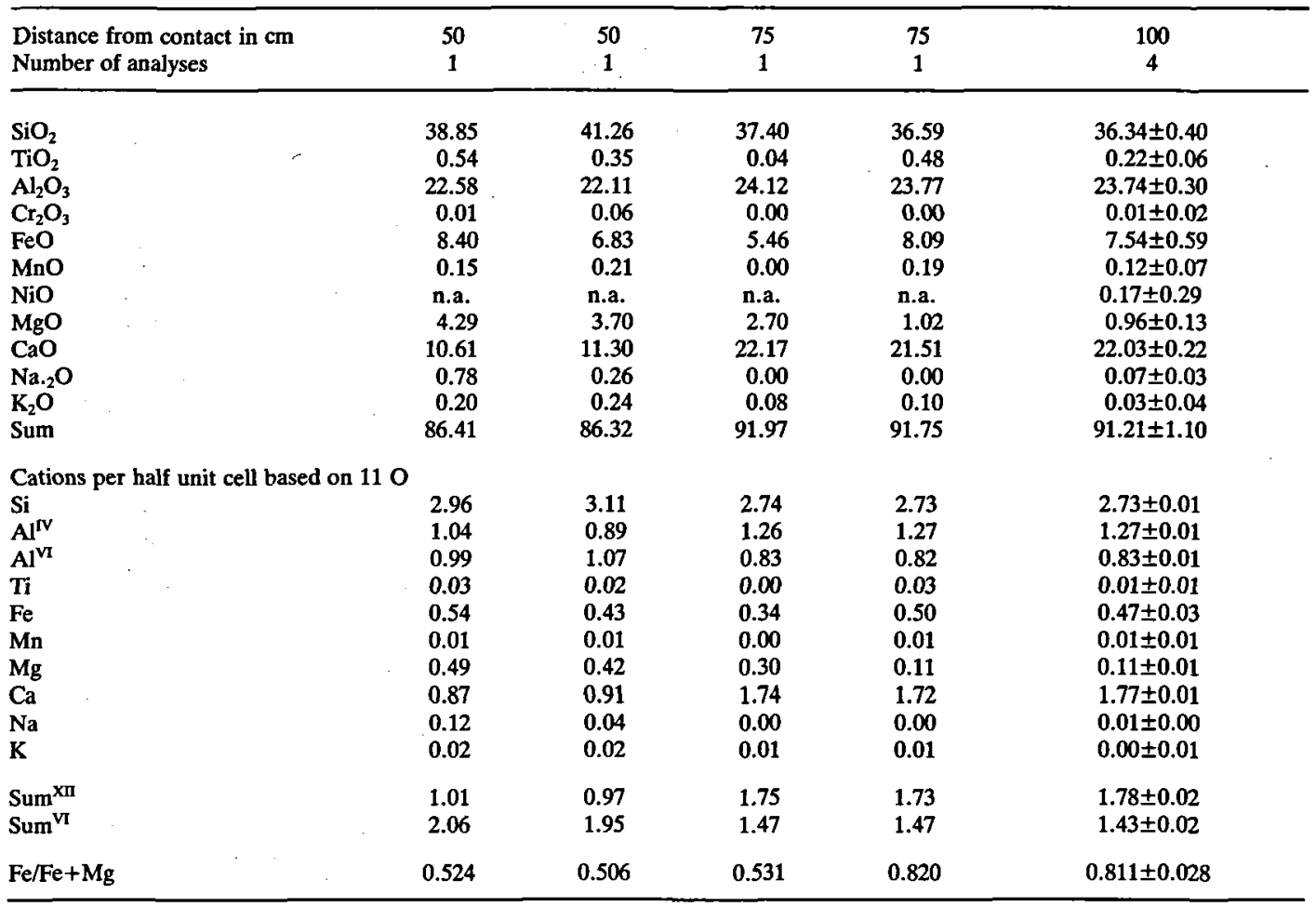

n.a. not analysed for

greenish and distinctly pleochroic. The composition of the chlorite has been determined by electron microprobe analysis in five samples of the B-profile taken from contact to middle of the dyke at $25 \mathrm{~cm}$ intervals. The results are shown in table 4.

According to the classification of Foster (1962) the chlorite is a brunsvigite; according to the nomenclature of Bayliss (1975) the chlorite should be termed magnesian chamosite.

It is not possible to make any safe conclusions about the variation in composition of the chlorite across the dyke, as the variation in composition between different chlorites occurring at the same distance from the contact is almost as great as the difference in composition between chlorites occurring at different distances from the contact. However, the results are consistent with a decrease in $\mathrm{Fe}$ and an increase in $\mathrm{Mg}$ from the contact until $75 \mathrm{~cm}$ from the contact, but from here to the middle of the dyke this trend is reversed.

As the analyses were made by electron microprobe water was not determined and there is no distinction between $\mathrm{Fe}^{++}$and $\mathrm{Fe}^{+++}$. It has, however, been calculated how much $\mathrm{Fe}^{+++}$is needed to satisfy the equation $R^{+++V I / 2 ~-~}$ $\mathrm{R}^{+++\mathrm{IV}} / 2=6-\mathrm{sum}^{\mathrm{V}}$. Assuming that the analyses are good enough to give a total between 99 and $100 \%$ if $\mathrm{H}_{2} \mathrm{O}$ had been determined, and thus using $\mathbf{1 0 0}$ (or 99) minus the sum of the analyses as $\mathrm{H}_{2} \mathrm{O}$ values, it has also been calculated how much $\mathrm{Fe}^{+++}$is needed to balance $36(\mathrm{O}+\mathrm{OH})$, where $\mathrm{O}$ and $\mathrm{OH}$ are calculated from the $\mathrm{O}$ values from the analyses. $\mathrm{Fe}^{+++}$values determined in this way are in good agreement with the $\mathrm{Fe}^{+++}$values determined by the equation $\mathrm{R}^{+++\mathrm{V} /} / 2-\mathrm{R}^{+++\mathrm{IV}} / 2$ $=6-$ sum $^{\mathrm{VI}}$, except in the contact sample where the sum of the analysis is too low to allow any $\mathrm{Fe}^{+++}$. Correspondence between the two values 
Table 6. Analyses of chlorite intergrown with mica

\begin{tabular}{|c|c|c|c|}
\hline $\begin{array}{l}\text { Distance from } \\
\text { contact in cm } \\
\text { Number of } \\
\text { analyses }\end{array}$ & $\begin{array}{l}50 \\
3\end{array}$ & $\begin{array}{l}75 \\
3\end{array}$ & $\begin{array}{l}100 \\
5\end{array}$ \\
\hline $\begin{array}{l}\mathrm{SiO}_{2} \\
\mathrm{TiO}_{2} \\
\mathrm{Al}_{2} \mathrm{O}_{3} \\
\mathrm{Cr}_{2} \mathrm{O}_{3} \\
\mathrm{FeO} \\
\mathrm{MnO} \\
\mathrm{NiO} \\
\mathrm{MgO} \\
\mathrm{CaO} \\
\mathrm{Na}_{2} \mathrm{O} \\
\mathrm{K}_{2} \mathrm{O} \\
\mathrm{Sum}\end{array}$ & $\begin{array}{r}27.49 \pm 0.49 \\
2.37 \pm 0.31 \\
16.39 \pm 0.13 \\
0.04 \pm 0.08 \\
32.65 \pm 0.69 \\
0.79 \pm 0.09 \\
\text { n.a. } \\
7.54 \pm 0.62 \\
0.28 \pm 0.09 \\
0.53 \pm 0.32 \\
1.74 \pm 0.30 \\
89.82 \pm 0.78\end{array}$ & $\begin{array}{r}26.52 \pm 0.66 \\
1.51 \pm 0.51 \\
16.99 \pm 0.39 \\
0.00 \pm 0.00 \\
34.20 \pm 1.00 \\
0.71 \pm 0.07 \\
\text { n.a. } \\
6.98 \pm 0.70 \\
0.36 \pm 0.06 \\
0.09 \pm 0.09 \\
1.00 \pm 0.67 \\
88.37 \pm 0.62\end{array}$ & $\begin{array}{r}27.90 \pm 0.40 \\
2.25 \pm 0.33 \\
16.03 \pm 0.23 \\
0.02 \pm 0.03 \\
30.77 \pm 0.70 \\
0.77 \pm 0.06 \\
0.04 \pm 0.04 \\
8.15 \pm 0.55 \\
0.59 \pm 0.39 \\
0.11 \pm 0.03 \\
1.80 \pm 0.44 \\
88.43 \pm 0.37\end{array}$ \\
\hline $\begin{array}{l}\text { Cations per ha } \\
\mathrm{Si} \\
\mathrm{Al}^{\mathrm{IV}} \\
\mathrm{Al}^{\mathrm{VI}} \\
\mathrm{Ti} \\
\mathrm{Fe} \\
\mathrm{Mn} \\
\mathrm{Mg} \\
\mathrm{Ca} \\
\mathrm{Na} \\
\mathrm{K}\end{array}$ & $\begin{array}{c}\text { alf unit cell ba } \\
2.99 \pm 0.03 \\
1.01 \pm 0.03 \\
1.09 \pm 0.01 \\
0.19 \pm 0.03 \\
2.97 \pm 0.08 \\
0.07 \pm 0.01 \\
1.22 \pm 0.10 \\
0.03 \pm 0.01 \\
0.11 \pm 0.07 \\
0.24 \pm 0.04\end{array}$ & $\begin{array}{c}\text { d on } 14 \mathrm{O} \\
2.94 \pm 0.05 \\
1.06 \pm 0.05 \\
1.17 \pm 0.03 \\
0.13 \pm 0.04 \\
3.18 \pm 0.12 \\
0.07 \pm 0.01 \\
1.16 \pm 0.11 \\
0.04 \pm 0.01 \\
0.02 \pm 0.02 \\
0.14 \pm 0.09\end{array}$ & $\begin{array}{l}3.05 \pm 0.03 \\
0.95 \pm 0.03 \\
1.12 \pm 0.02 \\
0.19 \pm 0.03 \\
2.81 \pm 0.09 \\
0.07 \pm 0.01 \\
1.33 \pm 0.08 \\
0.07 \pm 0.05 \\
0.03 \pm 0.01 \\
0.25 \pm 0.06\end{array}$ \\
\hline $\begin{array}{l}\text { Sum'v' } \\
\mathrm{Fe} / \mathrm{Fe}+\mathrm{Mg}\end{array}$ & $\begin{array}{c}5.94 \pm 0.04 \\
0.709 \pm 0.021\end{array}$ & $\begin{array}{c}5.90 \pm 0.04 \\
0.733 \pm 0.023\end{array}$ & $\begin{array}{c}5.87 \pm 0.02 \\
0.679 \pm 0.018\end{array}$ \\
\hline
\end{tabular}

n.a. not analysed for

'VI' sum of cations except $\mathrm{Si}$ and $\mathrm{Al}^{\mathrm{IV}}$

of $\mathrm{Fe}^{+++}$for the contact sample is obtained if the sum of analysis including $\mathrm{H}_{2} \mathrm{O}$ is assumed to be only a little less than $97 \%$. The number of $\mathrm{Fe}^{+++}$ ions obtained by these calculations is small, varying from 0.06 to 0.31 .

The values of the $\mathrm{Fe} / \mathrm{Fe}+\mathrm{Mg}$ ratio can not be used to confirm the correspondence between $\mathrm{Fe} /$ $\mathrm{Fe}+\mathrm{Mg}$ in chlorites and $\mathrm{Fe} / \mathrm{Fe}+\mathrm{Mg}$ in whole rock shown by Cathelineau \& Nieva (1985) for the range 0.2 to 0.8 of the $\mathrm{Fe} / \mathrm{Fe}+\mathrm{Mg}$ ratio as the differences obtained are not significant.

\section{Mica}

Next to feldspar and chlorite mica is the most abundant mineral in the Bjergebakke dyke. In the microscope the mica has a striking similarity to biotite, but the electron microprobe analyses show that we are dealing with a rather peculiar mica that is rich in $\mathrm{CaO}$ without being a margarite.

The electron microprobe analyses have revealed that not all that appears in the microscope to be mica is really mica. There is an intimate intergrowth between mica and a chlorite with a composition different from that of the chlorite in free grains. This intergrowth is similar to the intergrowth between albite and potassium feldspar and can be seen in the back scatter electron image of the microprobe as the chlorite intergrown with mica is somewhat lighter than the mica. Furthermore the difference under the microscope between the mica and the amphibole (only encountered in the sample $25 \mathrm{~cm}$ from the SW contact of the B-profile) is very subtle, the amphibole showing only a few degrees deviation from straight extinction. Unfortunately only amphibole analyses were obtained from this sample, but mica is certainly also present.

Analyses of mica are given in table 5. From these it can be seen that towards the centre $\mathrm{MgO}$ and $\mathrm{K}_{2} \mathrm{O}$ in the mica decreases and $\mathrm{CaO}$ increases and there is a pronounced increase in the ratio of $\mathrm{Fe} / \mathrm{Fe}+\mathrm{Mg}$ at the very centre.

\section{Chlorite intergrown with mica}

In the microscope chlorite intergrown with mica cannot be distinguished from the mica, but in the back scatter electron image of the microprobe the chlorite is somewhat lighter than the mica.

Table 6 shows the results of the electron microprobe analyses of the chlorite intergrown with mica at 50,75 and $100 \mathrm{~cm}$ distance respectively from the SW contact of the B-profile. No variation across the dyke can be seen, but comparison with table 4 shows that chlorite intergrown with mica is considerably richer in $\mathrm{K}$ and $\mathrm{Ti}$ and poorer in $\mathrm{Mg}$ than the chlorite in free grains. However, the chlorite intergrown with mica is, like the chlorite in free grains, a brunsvigite in the nomenclature of Foster (1962) and a magnesian chamosite in the nomenclature of Bayliss (1975).

\section{Amphibole}

In the Bjergebakke dyke amphibole is encountered only in the sample taken $25 \mathrm{~cm}$ from the 
Table 7. Amphibole analyses

Average of 5 analyses taken $25 \mathrm{~cm}$ from SW-contact

\begin{tabular}{|c|c|c|c|c|}
\hline $\mathrm{SiO}_{2}$ & $40.12 \pm 0.32$ & \multicolumn{3}{|c|}{ Cations based on 230} \\
\hline $\mathrm{TiO}_{2}$ & $4.62 \pm 0.07$ & $\mathrm{Si}$ & $5.92 \pm 0.04$ & \\
\hline $\mathrm{Al}_{2} \mathrm{O}_{3}$ & $12.90 \pm 0.27$ & $\mathrm{Al}^{\mathrm{IV}}$ & $2.08 \pm 0.03$ & Sum 8.00 \\
\hline $\mathrm{Cr}_{2} \mathrm{O}_{3}$ & $0.06 \pm 0.08$ & & & \\
\hline $\mathrm{FeO}$ & $14.56 \pm 1.44$ & $\mathrm{Al}^{\mathrm{VI}}$ & $0.16 \pm 0.01$ & \\
\hline $\mathrm{MnO}$ & $0.28 \pm 0.06$ & $\mathrm{Ti}$ & $0.52 \pm 0.02$ & \\
\hline MgO & $11.28 \pm 0.91$ & $\mathrm{Cr}$ & $0.01 \pm 0.02$ & \\
\hline $\mathrm{CaO}$ & $11.14 \pm 0.22$ & $\mathrm{Fe}^{+++}$ & $0.33 \pm 0.03$ & \\
\hline $\mathrm{Na}_{2} \mathrm{O}$ & $2.91 \pm 0.25$ & $\mathrm{Mg}$ & $2.48 \pm 0.18$ & \\
\hline $\mathrm{K}_{2} \mathrm{O}$ & $0.82 \pm 0.13$ & $\mathrm{Fe}^{++}$ & $1.48 \pm 0.14$ & \\
\hline \multirow[t]{4}{*}{ Sum } & $98.69 \pm 0.97$ & $\mathrm{Mn}$ & $0.04 \pm 0.02$ & Sum 5.02 \\
\hline & & $\mathrm{Na}$ & $0.83 \pm 0.08$ & \\
\hline & & $\mathrm{Ca}$ & $1.78 \pm 0.02$ & \\
\hline & & $\mathbf{K}$ & $0.15 \pm 0.02$ & Sum 2.76 \\
\hline
\end{tabular}

The distribution of $\mathrm{Fe}^{++}$and $\mathrm{Fe}^{+++}$is calculated by summing total cations except $\mathrm{Na}, \mathrm{Ca}$ and $\mathrm{K}$ to 13 (Robinson et al. 1982, p. 8)

SW contact of the B-profile. The appearance of the amphibole in the microscope is very similar to that of the mica, and the amphibole can only be distinguished from the mica by deviating a few degrees from straight extinction.

Table 7 shows the result of 5 electron microprobe analyses of the amphibole. It belongs to the group of calcic amphiboles and is a kaersutite (Hawthorne 1981).

\section{Opaque minerals}

The opaque minerals consist mainly of titanomagnetite which is generally more or less altered to maghemite and turbid sphene. Besides titanomagnetite there occur varying amounts of small thin laths of ilmenite and some grains of pyrite and chalcopyrite.

The size of the titanomagnetite grains lies mainly between $40 \mu \mathrm{m}$ and $80 \mu \mathrm{m}$. The dimensions of the ilmenite laths is about $1 \mu \mathrm{m} \times 30 \mu \mathrm{m}$. The pyrite grains can reach about $0.2 \mathrm{~mm}$ in diameter, but most pyrite grains lie between $5 \mu \mathrm{m}$ and $30 \mu \mathrm{m}$ in diameter. The chalcopyrite grains lie mainly between $5 \mu \mathrm{m}$ and $40 \mu \mathrm{m}$ in diameter, but a few grains are close to $0.1 \mathrm{~mm}$.

The distribution of ilmenite, pyrite and chalcopyrite across the dyke is similar and distinctive with minima in the middle and at the contacts, and maxima about halfway between contacts and middle. The total amount of these three minerals however is so small compared to the amount of titanomagnetite, that this distribution cannot be seen from the curve for ore shown in fig. 2, the shape of thin curve being determined by the amount of titanomagnetite.

The composition of the titanomagnetite has been investigated by electron microprobe analy-

Table 8. Analyses of titanomagnetite

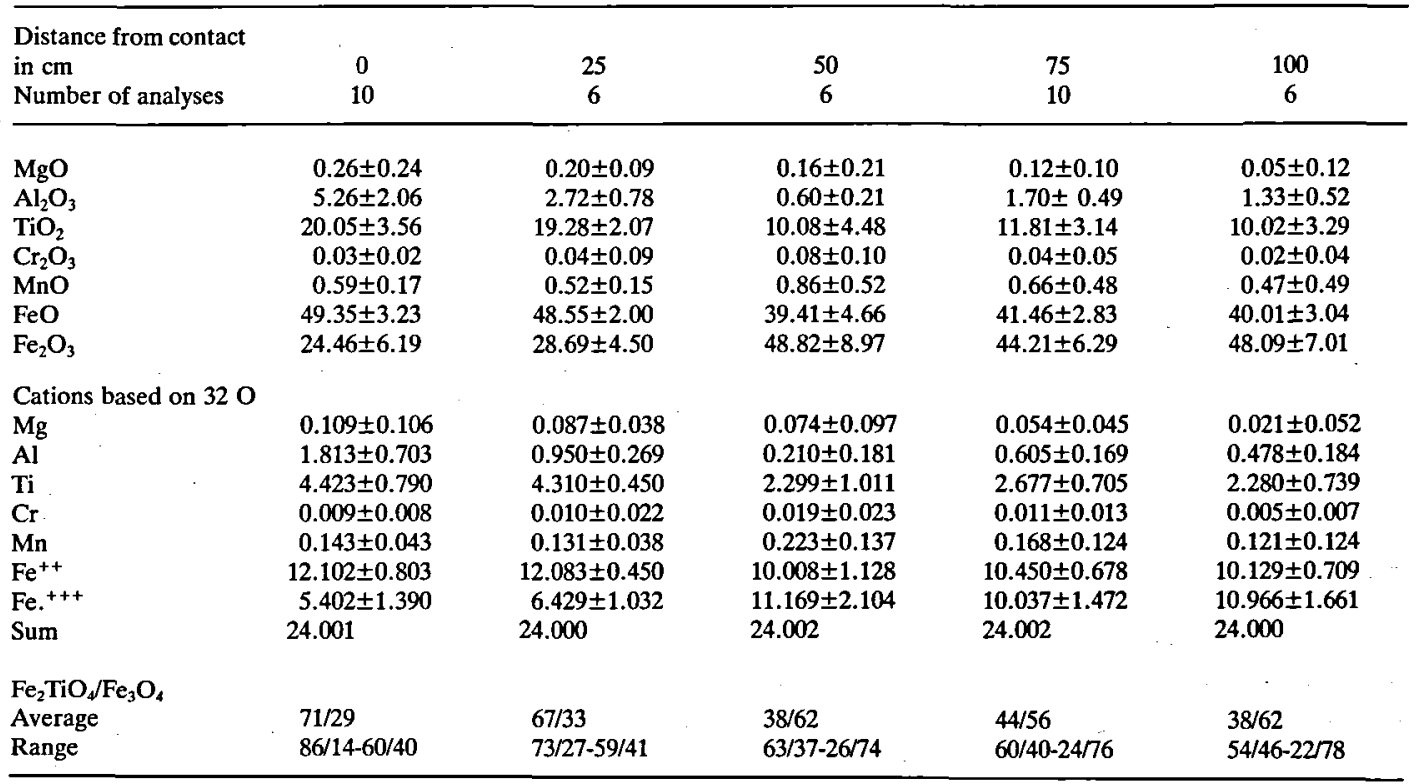


Table 9. Whole rock analyses

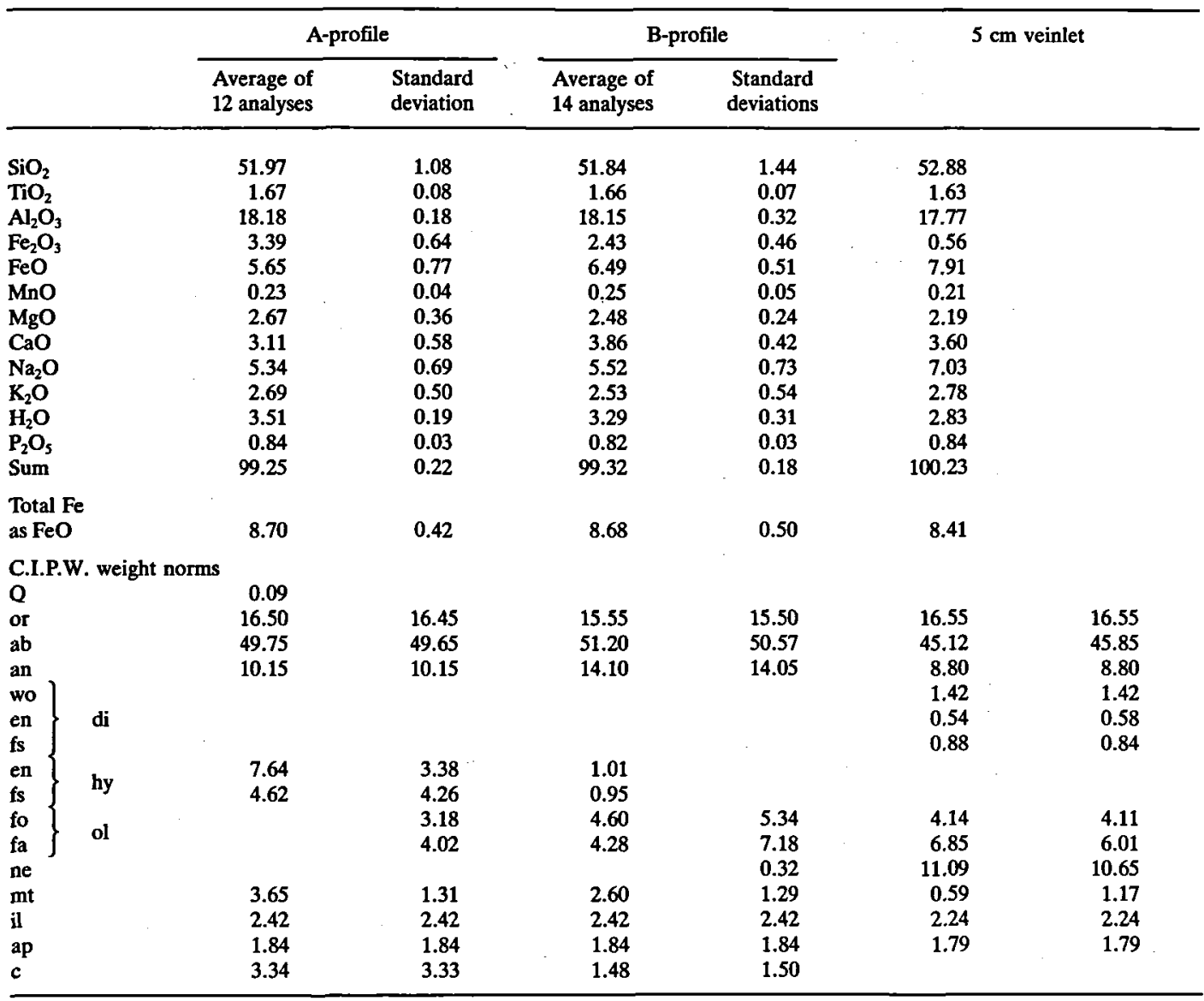

ses in a section from the SW contact to the centre of the B-profile.

Generally the outer parts of the ore grains were avoided during the electron microprobe analyses, but in the contact sample a few analyses of the rims were intentionally made.

The analysed grains all contain a small but varying amount of $\mathrm{SiO}_{2}$ and $\mathrm{CaO}$, obviously due to the alteration to turbid sphene. Accordingly the analyses have been recalculated to $100 \% \mathrm{mi}$ nus $\mathrm{SiO}_{2}$ and $\mathrm{CaO}$. The result is shown in table 8, the analysed rims from the contact sample being omitted.

The variation in composition between different grains at the same distance from the contact and different positions inside the same grain is rather large, but it can be seen that the amount of $\mathrm{TiO}_{2}$ decreases from the contact inwards. The range in $\mathrm{Fe}_{2} \mathrm{TiO}_{4} / \mathrm{Fe}_{3} \mathrm{O}_{4}$ indicates that this decrease continues right to the centre, whereas the average values of $\mathrm{Fe}_{2} \mathrm{TiO}_{4} / \mathrm{Fe}_{3} \mathrm{O}_{4}$ indicate that the decrease stops about $50 \mathrm{~cm}$ from the contact (the sample $75 \mathrm{~cm}$ from the contact is thought to be erroneously high).

$\mathrm{FeO}$ decreases with $\mathrm{TiO}_{2}$ and $\mathrm{Fe}_{2} \mathrm{O}_{3}$ shows a corresponding increase. $\mathrm{Cr}_{2} \mathrm{O}_{3}$, if present, is near the detection limit.

The analyses of the rims of titanomagnetite from the contact sample (not shown in table 8) have a $\mathrm{Fe}_{2} \mathrm{TiO}_{4} / \mathrm{Fe}_{3} \mathrm{O}_{4}$ ratio $49 / 51$ corresponding to a distance between 25 and $50 \mathrm{~cm}$ from the contact. This suggests that crystallisation at the contact was finished when the main crystallisation about $50 \mathrm{~cm}$ from the contact took place. 
Table 10. Trace element analyses

\begin{tabular}{|c|c|c|c|c|c|c|c|c|}
\hline & \multicolumn{3}{|c|}{ A-profile } & \multicolumn{4}{|c|}{ B-profile } & \multirow{3}{*}{$\begin{array}{c}5 \mathrm{~cm} \\
\text { veinlet }\end{array}$} \\
\hline & & & $\begin{array}{c}\text { Contact } \\
\text { only }\end{array}$ & & & $\begin{array}{l}\text { Contact } \\
0-3 \mathrm{~cm}\end{array}$ & $\begin{array}{l}\text { Contact } \\
3-6 \mathrm{~cm}\end{array}$ & \\
\hline & \multicolumn{3}{|c|}{ Standard deviation } & \multicolumn{3}{|c|}{ Standard deviation } & & \\
\hline $\mathbf{R b}$ & 96 & 19 & 68 & 89 & 27 & 34 & 82 & 71 \\
\hline $\mathrm{Ba}$ & 980 & 172 & 871 & 1052 & 167 & 531 & 1570 & 1520 \\
\hline $\mathrm{Pb}$ & 9 & 8 & 13 & 4 & 3 & 8 & 2 & 18 \\
\hline Sr & 696 & 144 & 788 & 886 & 128 & 559 & 998 & 423 \\
\hline La & 90 & 5 & 97 & 88 & 6 & 97 & 96 & 86 \\
\hline $\mathrm{Ce}$ & 169 & 10 & 179 & 174 & 14 & 202 & 188 & 187 \\
\hline Nd & 68 & 4 & 75 & 68 & 6 & 82 & 74 & 77 \\
\hline $\mathbf{Y}$ & 33 & 7 & 45 & 30 & 4 & 41 & 34 & 45 \\
\hline Th & 11 & $1 \frac{1}{2}$ & 13 & 10 & 2 & 11 & 11 & 11 \\
\hline $\mathrm{Zr}$ & 344 & $16^{-2}$ & 370 & 336 & 11 & 357 & 342 & 363 \\
\hline $\mathrm{Nb}$ & 108 & $2 \frac{1}{2}$ & 111 & 108 & 1 & 109 & 109 & 112 \\
\hline $\mathrm{Zn}$ & 65 & 15 & 83 & 55 & 10 & 71 & 58 & 52 \\
\hline $\mathrm{Cu}$ & 4 & 4 & $<3$ & $4 \frac{1}{2}$ & $3 \frac{1}{2}$ & $<3$ & $<3$ & $<3$ \\
\hline $\mathrm{Co}$ & 24 & 1 & 23 & 23 & 2 & 21 & 21 & 22 \\
\hline $\mathrm{Ni}$ & 3 & 2 & $<2$ & $<2$ & & $<2$ & $<2$ & $<2$ \\
\hline Sc & 6 & 1 & 5 & 6 & 1 & 5 & 5 & 5 \\
\hline V & 64 & 9 & 72 & 58 & 5 & 53 & 53 & 58 \\
\hline $\mathrm{Cr}$ & $<3$ & & $<3$ & $<3$ & & $<3$ & $<3$ & $<3$ \\
\hline $\mathrm{Ga}$ & 17 & 1 & 17 & 17 & $1 \frac{1}{2}$ & 22 & 16 & 16 \\
\hline $\mathbf{K} / \mathbf{Y}$ & 749 & 215 & 355 & 702 & 271 & 221 & 669 & 526 \\
\hline $\mathbf{K} / \mathbf{R} \mathbf{b}$ & 247 & 19 & 232 & 253 & 20 & 262 & 274 & 333 \\
\hline $\mathrm{Rb} / \mathrm{Th}$ & 8.8 & 2.2 & 5.4 & 8.4 & 3.4 & 3.3 & 7.5 & 6.5 \\
\hline $\mathrm{La} / \mathrm{Th}$ & 8.4 & 1.1 & 7.8 & 8.9 & 1.5 & 9.2 & 8.8 & 7.8 \\
\hline $\mathrm{Y} / \mathrm{Zr}$ & 0.09 & 0.01 & 0.12 & 0.09 & 0.01 & 0.11 & 0.10 & 0.12 \\
\hline
\end{tabular}

\section{Whole rock analyses}

\section{Major elements}

12 chemical analyses have been made from the A-profile and 14 from the B-profile; duplicate samples were made of the samples taken 60 and $90 \mathrm{~cm}$ from the NE contact of the A-profile and 25,50 and $125 \mathrm{~cm}$ from the SW contact of the B-profile. The $5 \mathrm{~cm}$ veinlet was analysed as a whole.

The analyses were carried out in the laboratory of the Geological Survey of Greenland by $\mathrm{Ib}$ Sørensen. $\mathrm{H}_{2} \mathrm{O}^{+}$was determined by the Penfield method and $\mathrm{Fe}^{++}$by wet chemistry. $\mathrm{Mg}$ was determined by complexometric titration, $\mathrm{Na}$ by flame photometry, and the remaining elements were analysed by XRF on glass discs.

Table 9 shows the average values of the two profiles and the values obtained for the $5 \mathrm{~cm}$ veinlet together with the calculated CIPW weight norms. The norms were calculated with the ratio $\mathrm{Fe}_{2} \mathrm{O}_{3} / \mathrm{FeO}$ as found by analyses (first column) as well as with this ratio adjusted to 0.15 (second column).

In the QAPF-diagram the averages of the Aand B-profiles both plot in the trachyte field whereas the $5 \mathrm{~cm}$ veinlet just reaches the tephritic phonolite field.

Most of the individual analyses of the two profiles also plot in the trachyte field with neither $Q$ nor $F$, but the two contact samples of the Aprofile plot in the alkali-trachyte field and have $Q$ (1.89 and 2.49 respectively), also the three central samples of the A-profile have $Q$ (max. 0.79) but plot in the trachyte field. The contact samples of the B-profile plot near the border to the alkalitrachyte field. No analyses of the B-profile have $Q$, but the samples $3-6 \mathrm{~cm}$ and $25 \mathrm{~cm}$ from the SW contact and the sample $0-3 \mathrm{~cm}$ from the NE contact have a small amount of $F$ ( $\max .1 .17 \mathrm{ne}$ ).

Use of the CIPW weight norms with the $\mathrm{Fe}_{2} \mathrm{O}_{3} /$ $\mathrm{FeO}$ ratio adjusted to 0.15 does not result in change of fields but $Q$ disappears from the Aprofile without any ne being introduced, and the amount of ne in the B-profile increases.

In the TAS diagram (Le Bas et al. 1986) the 


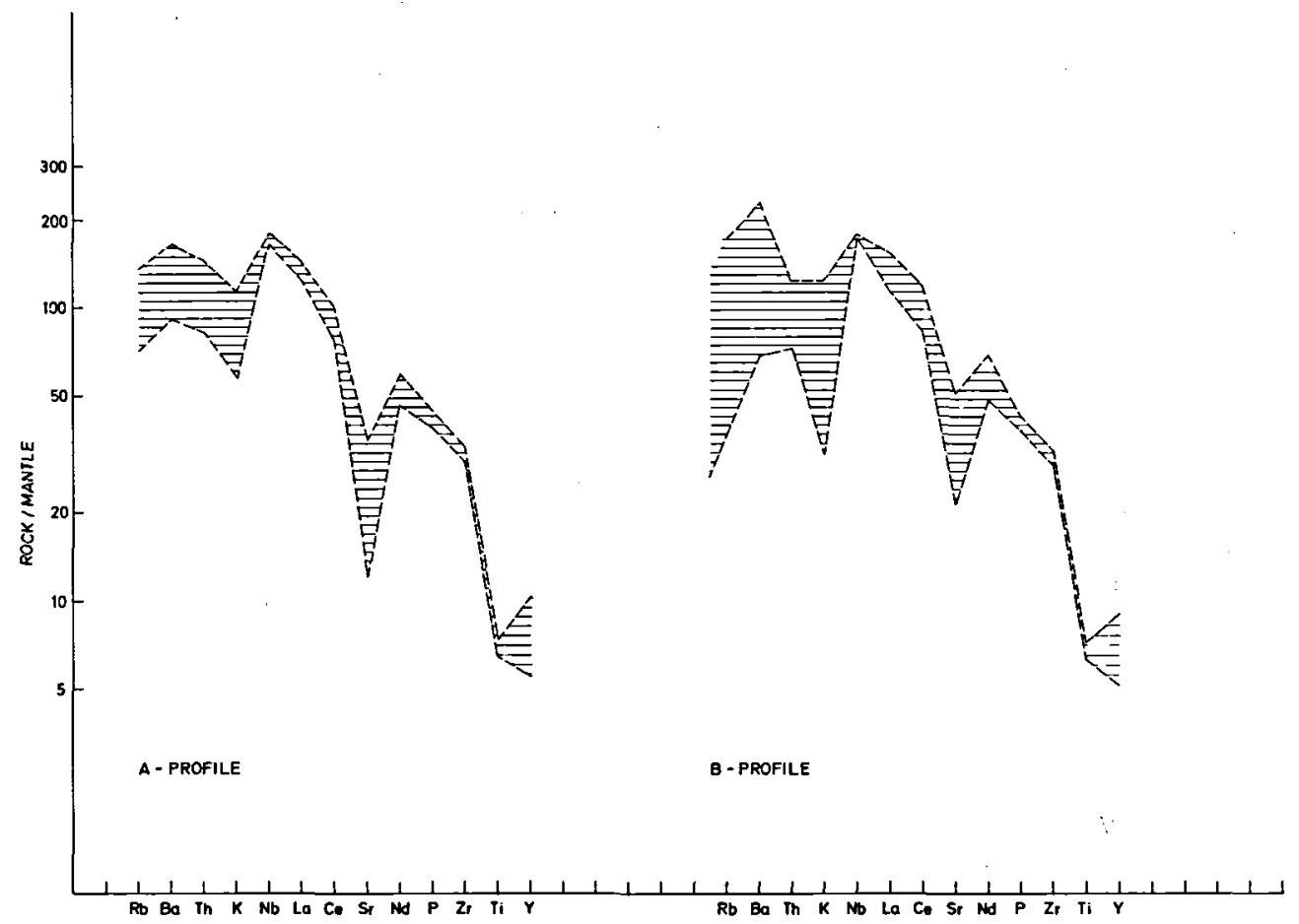

Fig. 4. 'Spidergrams' for the two profiles. The element concentrations are normalised to 'primordial mantle' values, and arranged from left to right in order of decreasing incompatibility (Wood et al. 1979)

averages of the A- and B-profiles both plot on the border between the trachyandesite and the basaltic trachyandesite fields, whereas the $5 \mathrm{~cm}$ veinlet plots on the border between the trachyandesite and the tephriphonolite fields. The contact analyses of both profiles plot in the trachyandesite field while all the other analyses plot in the basaltic trachyandesite field.

The analyses, however, all have about $3 \%$ water. A main reason for this investigation of the Bjergebakke dyke is its close resemblance to the kullaites from Scania described by Hennig (1899) and Hjelmqvist (1930), and classified by Johannsen (1937) as syenodiorite porphyries (2211'A). The kullaites also have a large amount of water: 2.76 and $2.59 \%$ in the two analyses published by Johannsen (1937) and 3.69 and $4.00 \%$ in two recent analyses (personal communication Hans Olsson).

\section{Trace elements}

Trace elements were analysed directly on pressed powder pellets by J.Bailey, Institute of Petrol- ogy, University of Copenhagen, by X-ray fluorescence using a Phillips PW 1400 (funded by the Danish Natural Science Research Council) and the techniques of Norrish \& Chappell (1977).

Table 10 gives the average composition of the two profiles and the composition of the contacts and of the $5 \mathrm{~cm}$ veinlet.

The values of $\mathrm{Sr}, \mathrm{La}$ and $\mathrm{Nb}$ are unusually high, and for a rock of trachytic composition the values of $Y, C o$ and $V$ are high and the values of $\mathrm{Rb}, \mathrm{Zr}, \mathrm{Zn}$ and $\mathrm{Ga}$ are low. Wood et al. (1979) found the highest ratio of $\mathrm{K} / \mathrm{Y}$ (a highly incompatible element against a slightly incompatible element) in alkalibasalts erupted in the southern part of the eastern active zone in Iceland, this value being 190 .

The contacts of the Bjergebakke dyke are depleted in $\mathrm{K}$ relative to $\mathrm{Y}$ with $\mathrm{K} / \mathrm{Y}$ ratios of 355 and 221 for the two profiles respectively, whereas the interior of the dyke has $\mathrm{K} / \mathrm{Y}$ ratios about 850 . Wood et al. (1979) consider such a large variation to rule out a relation to a single parental liquid by low pressure crystal fractionation. In the Bjergebakke dyke, however, the depletion in $\mathrm{K}$ at the 

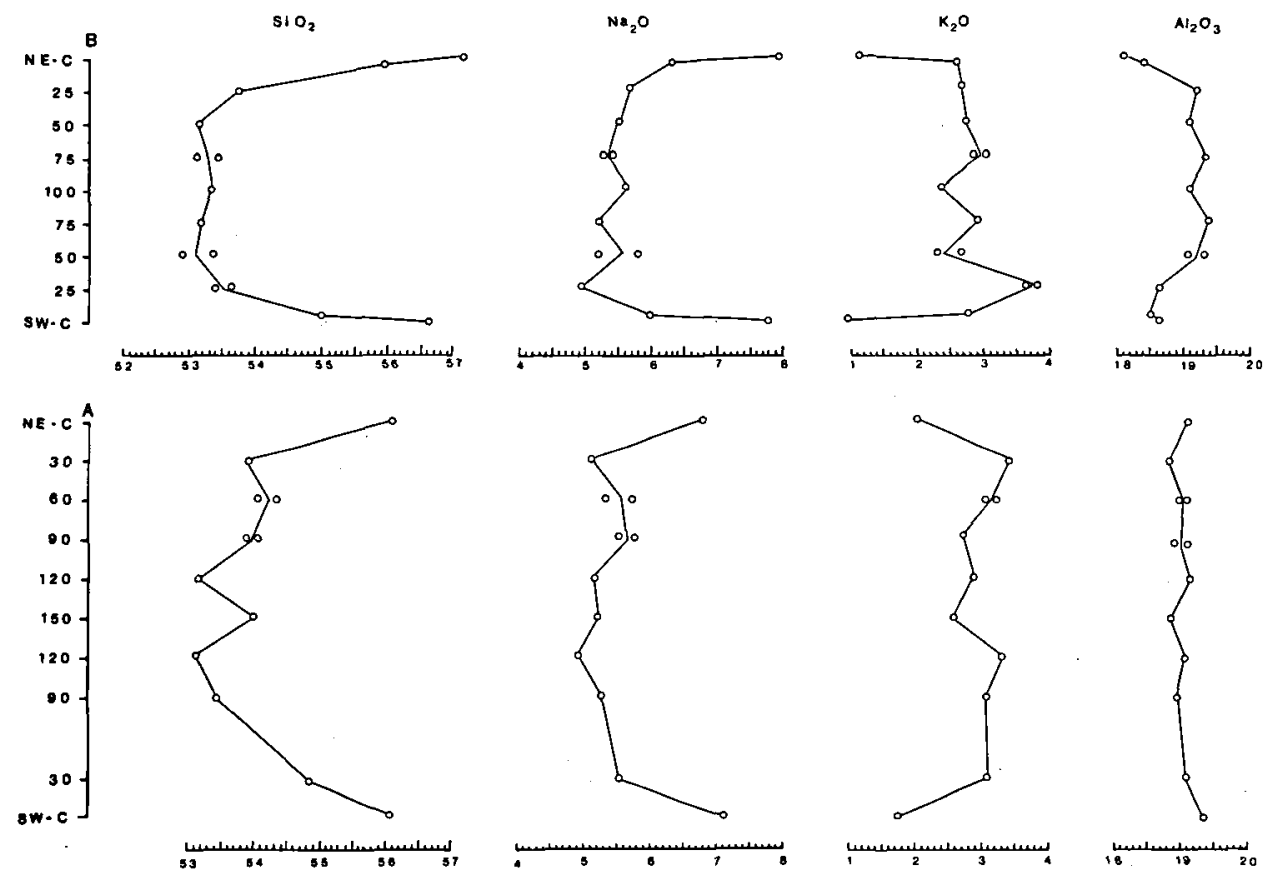

Fig. 5. Variations across the dyke in $\mathrm{SiO}_{2}, \mathrm{Na}_{2} \mathrm{O}, \mathrm{K}_{2} \mathrm{O}$ and $\mathrm{Al}_{2} \mathrm{O}_{3}$

contacts could be due to later autometasomatic processes.
The ratio of $\mathrm{K} / \mathrm{Rb}$ is rather constant across the dyke with average values of 247 and 253 for the
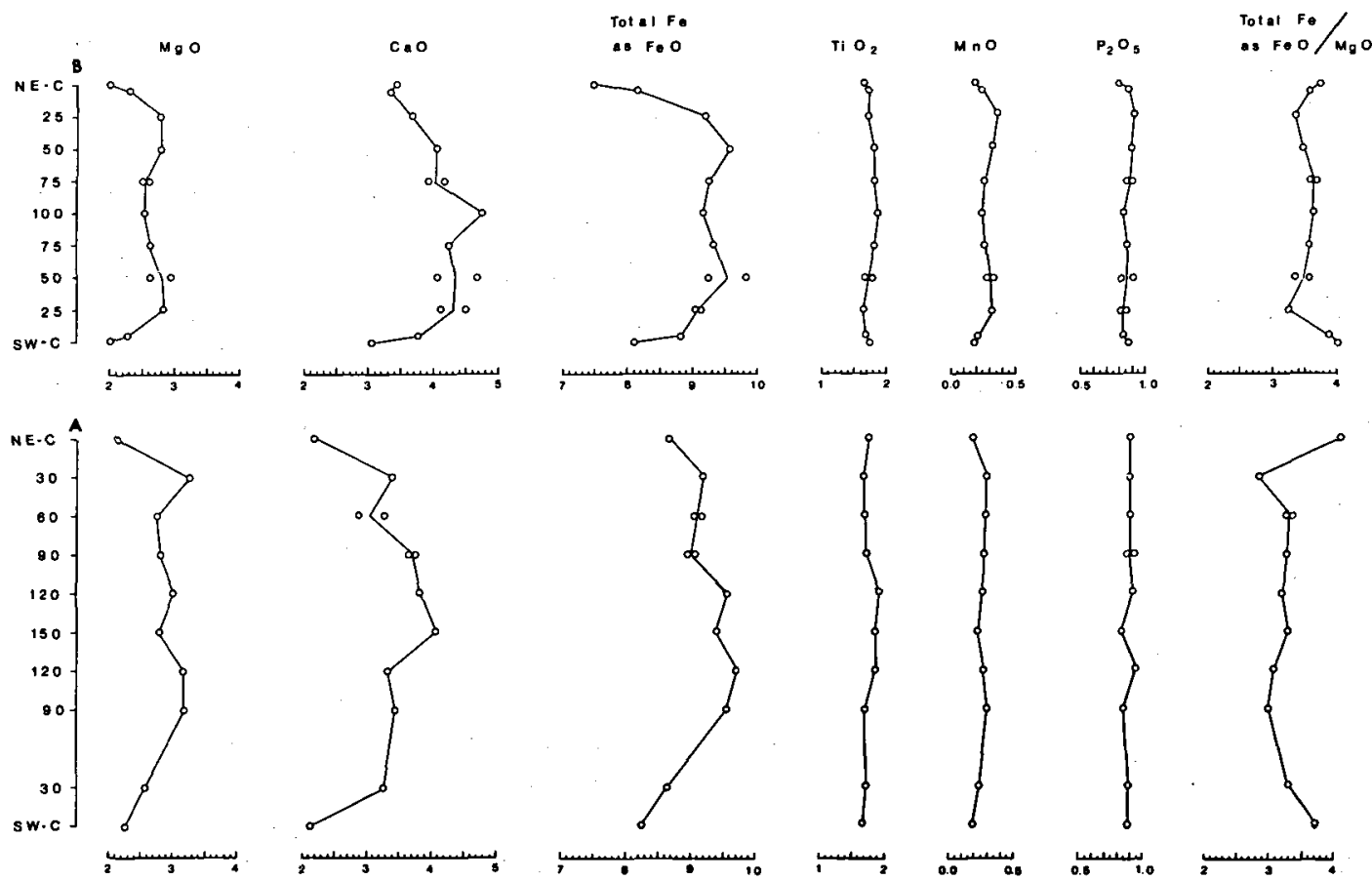

Fig. 6. Variations across the dyke in $\mathrm{MgO}, \mathrm{CaO}$, total $\mathrm{Fe}$ as $\mathrm{FeO}, \mathrm{TiO}_{2}, \mathrm{MnO}, \mathrm{P}_{2} \mathrm{O}_{5}$ and the ratio of total $\mathrm{Fe}$ as $\mathrm{FeO}$ to $\mathrm{MgO}$ 
two profiles respectively, which, however, are lower than the ratio in the bulk Earth ( 300 ; Ganapathy \& Anders 1974). The value of $K / R b$ for the $5 \mathrm{~cm}$ veinlet exceeds 300 .

The average ratio of $\mathrm{Rb} / \mathrm{Th}$ of the two profiles is 8.8 and 8.4 respectively which is close to the value of 9 in the bulk Earth (Ganapathy \& Anders 1974), but the contacts are depleted in $\mathrm{Rb}$ relative to Th having a $\mathrm{Rb} / \mathrm{Th}$ ratio of 5.4 .

The average ratio of $\mathrm{La} / \mathrm{Th}$ of the two profiles is 8.4 and 8.9 respectively, which is higher than the ratio of 7.4 in the bulk Earth (Ganapathy \& Anders 1974), but the $5 \mathrm{~cm}$ veinlet and the contacts of the A-profile have a value of 7.8.

The $\mathrm{Y} / \mathrm{Zr}$ ratio is somewhat higher for the contacts than in the interior of the dyke.

Fig. 4 shows "spidergrams" for the two profiles. The element concentrations are normalised to "primordial mantle" values, and arranged from left to right in order of decreasing incompatibility (Wood et al. 1979).

\section{Chemical variations}

\section{Major elements}

The variations in chemical composition for major elements across the dyke are shown in figs 5 and 6. The values used are recalculated to $100 \%$ based on water-free composition, but the use of the oxide values found by chemical analyses does not change either the trends or the shape of the curves. In the A-profile two analyses were made of the samples taken 60 and $90 \mathrm{~cm}$ from the NE contact. In the B-profile two analyses were made of the samples taken 25,50 and $125 \mathrm{~cm}$ from the SW contact. Where only one point is shown in the figures for these samples the two analyses have given identical values.

Across the dyke the value of $\mathrm{SiO}_{2}$ decreases abruptly from the contacts inwards and then a weak increase against the centre of the dyke can be noted.

The behaviour of $\mathrm{Al}_{2} \mathrm{O}_{3}$ is peculiar. Both profiles show a minimum at the centre, but while in the A-profile $\mathrm{Al}_{2} \mathrm{O}_{3}$ decreases inwards from the contacts all the way to the centre, in the B-profile it first increases.

$\mathrm{Na}_{2} \mathrm{O}$ decreases abruptly from the contacts inwards and there are some undulations across the dyke, including a weak maximum at the centre.
$\mathrm{K}_{2} \mathrm{O}$ increases abruptly from the contacts inwards and then undulates across the dyke, including a weak minimum at the centre.

$\mathrm{CaO}$ increases from the contacts inwards and shows a maximum at the centre of the dyke. Also $\mathrm{MgO}$ increases from the contacts inwards; the fluctuations across the dyke include a weak minimum at or near the centre.

$\mathrm{TiO}_{2}$ is somewhat higher in the central parts of the dyke than in the border parts. Total $\mathrm{Fe}$ as $\mathrm{FeO}$ increases from the contacts inwards and shows a minimum at the centre.

$\mathrm{Fe}_{2} \mathrm{O}_{3}$ (not shown) decreases from the contacts inwards and then increases towards the centre, whereas $\mathrm{FeO}$ (not shown) increases from the contacts inwards and then decreases towards the centre.

$\mathrm{MnO}$ and $\mathrm{P}_{2} \mathrm{O}_{5}$ are fairly constant, but both may show a weak minimum at the centre. $\mathrm{MnO}$ furthermore shows a weak initial increase from the contacts inwards.

\section{Trace elements}

The distribution of trace elements across the dyke is not shown in a figure but tentatively described in the following:

$\mathrm{Rb}$ and $\mathrm{Ba}$ behave similarly to $\mathrm{K}_{2} \mathrm{O}$. The behaviour of $\mathrm{Sr}$ resembles $\mathrm{K}_{2} \mathrm{O}$ and that of $\mathrm{Zr}$ resembles $\mathrm{SiO}_{2}$.

$\mathrm{La}, \mathrm{Ce}, \mathrm{Nd}$ and $\mathrm{Zn}$ have a minimum at the centre and increase towards the contacts.

$Y$ decreases from the contacts inwards and is rather constant in the interior of the dyke.

$\mathrm{Pb}, \mathrm{V}, \mathrm{Th}, \mathrm{Nb}, \mathrm{Cu}$ and $\mathrm{Ni}$ vary, and $\mathrm{Pb}$ and $\mathrm{V}$ fluctuate.

$\mathrm{Co}, \mathrm{Sc}$ and $\mathrm{Cr}$ are rather constant across the dyke, and so is $\mathrm{Ga}$ except for an increase at the actual contact shown only in the B-profile (which shows up probably because the contact sample here was split into two pieces, one $0-3$ and the other 3-6 cm from the contact).

When plotted against $\mathrm{Rb}$ on $\log -\log$ paper only the highly incompatible elements $B a$ and $K$ result in $45^{\circ}$ lines, although concerning $B a$ the contact samples are too high in $\mathrm{Ba}$ to fit the $45^{\circ}$ line. When the contact samples are omitted the $45^{\circ}$ direction can also be seen for the elements $\mathrm{Nd}$ and $\mathrm{Zr}$; however, for these elements it would not be correct to talk about a line, rather a band. The 
contact samples are too high in $\mathrm{Nd}$ and $\mathrm{Zr}$ to fit the otherwise established band.

When plotted against $\mathrm{Zr}$ on log-log paper no $45^{\circ}$ lines are seen for any element, but $45^{\circ}$ bands can be established for $\mathrm{Nb}$ (only in the A-profile), $\mathrm{Ce}, \mathrm{Nd}$ and $\mathrm{Y}$. When the contact samples are omitted $45^{\circ}$ bands can also be established for $\mathrm{Rb}$ (only in the A-profile), Ba (only in the A-profile) and $K$, but the contact samples are too low in these elements to fit the otherwise established band.

\section{Composition of the $5 \mathrm{~cm}$ veinlet}

When the $5 \mathrm{~cm}$ veinlet was sampled in full width it was thought that the veinlet was so thin that it probably did not extend upwards for more than a few metres, so that the intruding magma was prevented in penetrating further upwards. The composition of the veinlet in full width possibly therefore represented the average of the magma.

Comparing the composition of the $5 \mathrm{~cm}$ veinlet (trace elements as well as major elements) with the variations across the dyke it is seen that the 5 $\mathrm{cm}$ veinlet does not correspond to the average composition of the dyke but to the composition found between 5 and $10 \mathrm{~cm}$ from the contacts. This could be interpreted as a result of the veinlet opening did not take place until the first 5 to $\mathbf{1 0}$ $\mathrm{cm}$ of the main dyke had solidified, but the present composition of the $5 \mathrm{~cm}$ veinlet could also be the result of a different degree of later autometasomatic alteration.

\section{Analyses of the granite country-rock}

In an attempt to find out to what extent the intrusion of the Bjergebakke dyke with its $1 \mathrm{~cm}$ alteration zone of albite influenced the granite country-rock, analyses were made of granite samples taken $5 \mathrm{~cm}, 50 \mathrm{~cm}, 3 \mathrm{~m}$ and $16 \mathrm{~m}$ from the contact in two different profiles, one at the northwest wall of the quarry and one at the southwest wall.

No significant differences can be seen concerning major elements except for a slight increase in $\mathrm{FeO}$ and decrease in $\mathrm{Fe}_{2} \mathrm{O}_{3}$ from $5 \mathrm{~cm}$ to $3 \mathrm{~m}$ from the contact without however any change in total Fe.
Concerning trace elements, $\mathrm{Rb}, \mathrm{Ba}$ and $\mathrm{Y}$ increase from $5 \mathrm{~cm}$ from the contact until $3 \mathrm{~m}$ from the contact, $\mathrm{Rb}$ from 195 to $230 \mathrm{ppm}, \mathrm{Ba}$ from 640 to $740 \mathrm{ppm}$ and $Y$ from 40 to $50 \mathrm{ppm}$. $\mathrm{Zn}$ increases from 1 to $15 \mathrm{ppm}$ in the interval $5 \mathrm{~cm}$ to $50 \mathrm{~cm}$ from the contact.

Any further chemical changes because of the dyke intrusion must be confined to the few $\mathrm{cm}$ of the granite nearest to the contact.

\section{Significance of the chemical variations}

The variations across the dyke in $\mathrm{SiO}_{2}, \mathrm{Na}_{2} \mathrm{O}$, $\mathrm{MgO}, \mathrm{CaO}$, total $\mathrm{Fe}$ as $\mathrm{FeO}$ and the ratio of total $\mathrm{Fe}$ as $\mathrm{FeO}$ against $\mathrm{MgO}$ indicate a development from the contacts inwards from felsic to mafic.

It is not uncommon to find dykes with a felsic to mafic trend from margin to interior. Ross (1983) has found such a trend in Columbia River basalt dykes from the southeastern Columbia Plateau. Ross attributed the chemical trend to the relative enrichment in silica and incompatible elements in the glass and therefore in the glassy dyke margins compared to their more crystalline interiors. Also Kalsbeek \& Taylor (1985) found a felsic to mafic trend from margins to interior in dykes from Greenland. Kalsbeek \& Taylor interpreted the variations across the dykes as the result of the dyke material being tapped from a zoned magma chamber in which the magma near the roof was more fractionated, whereas the magma deeper down was less fractionated and contained large amounts of early crystallised olivine, augite and plagioclase. Kalsbeek \& Taylor (1986) also investigated variations across a $100 \mathrm{~m}$ wide basic dyke which can be followed $400 \mathrm{~km}$ along strike in central West Greenland and found a felsic to mafic trend from margins to interior, and interpreted the variations as due to a combination of enrichment of early formed crystals in the central part of the dyke, and intrusion of more fractionated magma at first, followed by more primitive magma.

The variations in the Bjergebakke dyke are similar to those found by Kalsbeek \& Taylor $(1985,1986)$ except that in the Bjergebakke dyke $\mathrm{K}_{2} \mathrm{O}$ increases from the contacts inwards.

During this work the author has been tempted to interpret the variations from the contacts inwards as due to preeruptional differentiation so 
Table 11. Whole rock analyses

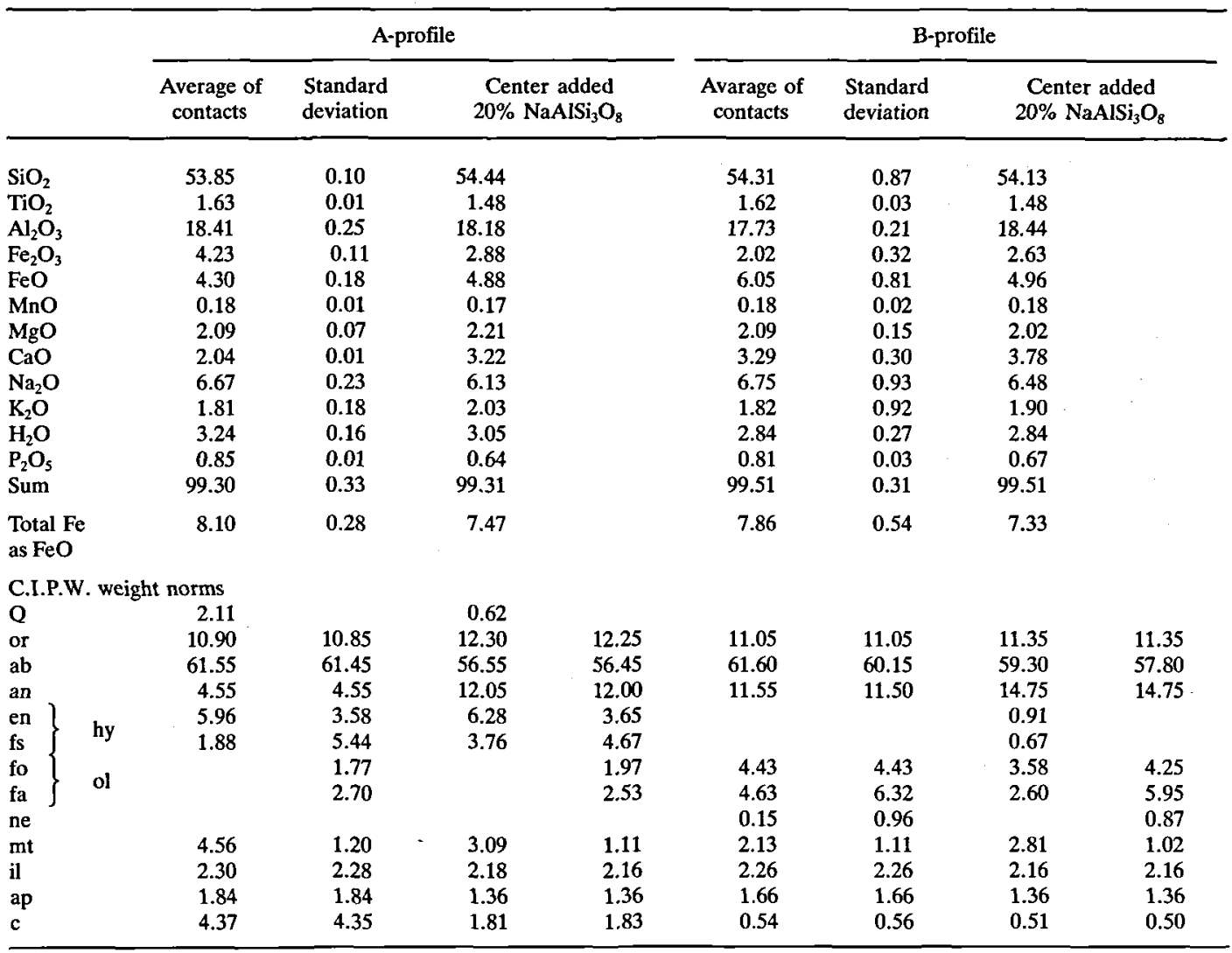

that the magma first erupted was more differentiated than the later erupted magma, and the variations in the central part of the dyke as due to posteruptional differentiation, but the behaviour of $\mathrm{K}_{2} \mathrm{O}$ and the fact that the dyke has suffered from later autometasomatic processes as shown for instance by the presence of the one $\mathrm{cm}$ thick borderzone of pure albite makes such an interpretation rather unsafe.

Therefore it has been calculated what effect the addition to the centre samples of different amounts of $\mathrm{NaAlSi}_{3} \mathrm{O}_{8}$ would have, and it is found that the addition of $20 \%$ albite to the centre sample analyses results in compositions very similar to those of the contact samples (table 11). The norms were calculated with the ratio $\mathrm{Fe}_{2} \mathrm{O}_{3}$ / $\mathrm{FeO}$ as found by analyses (first column) as well as with this ratio adjusted to 0.15 (second column). The contact samples, however, are somewhat enriched in $\mathrm{Na}_{2} \mathrm{O}$, total $\mathrm{Fe}, \mathrm{TiO}_{2}$ and $\mathrm{P}_{2} \mathrm{O}_{5}$ and depleted in $\mathrm{CaO}$ and $\mathrm{K}_{2} \mathrm{O}$ relative to the mod- ified centre samples. The behaviour of $\mathrm{SiO}_{2}$ and $\mathrm{Al}_{2} \mathrm{O}_{3}$ is opposite in the two profiles. From the B-profile where the contacts are represented by samples 0-3 and 3-6 cm from the contact respectively, it can be seen that the enrichment in $\mathrm{Na}_{2} \mathrm{O}$ relative to $\mathrm{K}_{2} \mathrm{O}$ takes place very close to the contact - between 3 and $6 \mathrm{~cm}$.

On these grounds the author finds that the chemical variations across the dyke therefore most probably are due to later autometasomatic alteration, mainly in the form of albitisation.

\section{Conclusions}

In the TAS diagram the contact samples of the Bjergebakke dyke plot in the trachyandesite field, whereas all the samples from the interior of the dyke plot in the basaltic trachyandesite field. 
The feldspar present is an intimate intergrowth of albite with the composition Ab 95.1 An 3.8 Or 1.1 and potassium feldspar with the composition Or 95.9 Ab 3.6 An 0.6.

There are no original dark silicate minerals left in the Bjergebakke dyke, they are completely altered to amphibole, mica or chlorite.

The composition of the chlorite seems to decrease in $\mathrm{FeO}$ and increase in $\mathrm{MgO}$ from contact to $75 \mathrm{~cm}$ from the contact, from here to the centre this trend is reversed.

The composition of the mica decreases in $\mathrm{MgO}$ and $\mathrm{K}_{2} \mathrm{O}$ and increases in $\mathrm{CaO}$ from contact to centre, the $\mathrm{Fe} / \mathrm{Fe}+\mathrm{Mg}$ ratio is very high at the centre.

The composition of the titanomagnetite decreases in $\mathrm{TiO}_{2}$ from the contact inwards.

The chemical variations across the dyke could be interpreted as due to preeruptional differentiation at and near the contacts, and to posteruptional differentiation in the central part of the dyke, but it is believed that the present distribution of elements across the dyke is caused by later autometasomatic alteration, mainly in the form of albitisation. As regards both orientation and mineralogical and chemical composition the Bjergebakke dyke is quite similar to the kullaites in Scania, but whereas all the dykes in the Precambrian of Bornholm have hitherto been considered Precambrian, the kullaites are considered post Silurian.

A preliminary age determination by Poul Martin Holm, Institute of Petrology, University of Copenhagen, has shown the kullaite from Scania to be older than the Bjergebakke dyke. No final decision as to the age of these dykes can be made before further age determinations of both Scania kullaite and the Bjergebakke dyke, as well as some of the dolerites of Bornholm, have been carried out.

\section{Acknowledgements}

Thanks are due to Mr. Luis Caceres for drawing the figures and to T. C. R. Pulvertaft for kindly improving the English of the manuscript. The Jeol Superprobe on which the analyses were carried out was bought with funds from the Danish Natural Science Research Council, and is run under the supervision of J. Rønsbo, Institute of Mineralogy, University of Copenhagen, whose assistance with the analyses is greatly appreciated.

\section{Dansk sammendrag}

I stenbruddet ved Bjergebakke, der ligger lige nord for vejen mellem Rønne og Svaneke $9 \mathrm{~km} \emptyset$ st for Rønne, skæres Almindingen-graniten af en 2-3 m bred gang. Gangen er næsten lodret og stryger NW-S $\emptyset\left(130^{\circ} / 88^{\circ} \mathrm{SW}\right)$. Denne retning er væsentligt afvigende fra retningen af de bornholmske doleriter, og Bjergebakkegangen har da heller ikke doleritisk sammensætning, men sảvel retning som sammensætning af Bjergebakkegangen svarer ganske nøje til de skånske kullaiter, det vil sige gangen består væsentligst af plagioklas, kalifeldspat, chlorit, biotit og titanomagnetit.

Grænsen mellem Bjergebakkegangen og Almindingen-graniten udgøres af en $1 \mathrm{~cm}$ mægtig hvid omdannelseszone, der næsten udelukkende består af albit.

Bjergebakkegangen er undersøgt $i$ to profiler, et $3 \mathrm{~m}$ bredt A-profil og et $2 \mathrm{~m}$ bredt B-profil (Fig. 1). I A-profilet er der taget prøver med $30 \mathrm{~cm}$ afstand, i B-profilet med $25 \mathrm{~cm}$ afstand. Der er også undersøgt prøver af en $5 \mathrm{~cm}$ bred udløber, der findes pả NW-væggen $50 \mathrm{~cm}$ W for hovedgangen. Udløberen fortsætter ind i væggen, men tynder ud og forsvinder efter 80 $\mathrm{cm}$. Gravning $\mathrm{i}$ bunden af bruddet har vist, at udløberen er forbundet med hovedgangen. Endvidere er Almindingen-graniten undersøgt i $5 \mathrm{~cm}, 50 \mathrm{~cm}, 3 \mathrm{~m}$ og $16 \mathrm{~m}$ afstand fra gangkontakten $i$ to profiler, et på bruddets NW-væg og et på SW-væggen.

Den gennemsnitlige modale sammensætning af de to profiler er vist i tabel 1, variationen på tværs af gangen er vist i fig. 2.

Tabel 2 og 3 viser sammensæetningen af henholdsvis plagioklas og kalifeldspat på tvars af gangen, og fig. 3 viser, hvor tæt disse mineraler er sammenvoksede.

Tabel 4, 5 og 6 viser sammensætningen på tværs af gangen for henholdsvis chlorit, glimmer og chlorit sammenvokset med glimmer.

Tabel 7 viser analyser af amfibol, der kun er fundet i en af prøverne, nemlig prøven $25 \mathrm{~cm}$ fra SW-kontakten af B-profilet.

Tabel 8 viser variationen af titanomagnetit på tværs af gangen.

Tabel 9 og 10 er bjergartsanalyser af henholdsvis hoved- og sporelementer. Fig. 5 og 6 viser variationen på tværs af gangen for hovedelementerne, og fig. 4 viser 'spidergrams' for sporelementerne.

Endelig sammenligner tabel 11 sammensatningen af kontaktprøverne med prøverne fra gangmidten, hvis disse tilføres $20 \%$ albit.

I TAS diagrammet falder kontaktprøverne af Bjergbakkegangen i trakyandesitfeltet, medens alle øvrige prøver falder $\mathrm{i}$ feltet for basaltisk trakyandesit.

Variationerne i mineralernes sammensætning på tværs af gangen er meget små, og ofte er forskellen mellem forskellige prøver ikke større end forskellene mellem forskellige korn i samme prøve. Tydeligst ses det, at Ti-indholdet $\mathrm{i}$ titanomagnetiten falder fra kontakten indefter $i$ gangen.

Den kemiske sammensatning af den $5 \mathrm{~cm}$ brede udløber svarer til den kemiske sammensætning af gangen i 5 til $10 \mathrm{~cm}$ afstand fra kontakten og viser sảledes ikke, som forventet ved prøveudtagningen, gangens gennemsnitssammensatning.

Analyserne af Almindingen-graniten taget henholdsvis $5 \mathrm{~cm}$, $50 \mathrm{~cm}, 3 \mathrm{~m}$ og $16 \mathrm{~m}$ fra gangkontakten viser kun ganske små forskelle. For hovedelementernes vedkommende er den eneste variation, at der er en svag stigning i FeO fra $5 \mathrm{~cm}$ til $3 \mathrm{~m}$. Denne stigning er ledsaget af et tilsvarende fald i $\mathrm{Fe}_{2} \mathrm{O}_{3}$, sả total jern er uændret. Af sporelementerne viser $\mathrm{Rb}, \mathrm{Ba}$ og $\mathrm{Y}$ stigning fra $5 \mathrm{~cm}$ til $3 \mathrm{~m}, \operatorname{og~} \mathrm{Zn}$ fra $5 \mathrm{~cm}$ til $50 \mathrm{~cm}$. Yderligere ændringer i Almindingen-granitens sammensætning som følge af gangintrusionen må derfor være begrænset til de $5 \mathrm{~cm}$ nærmest gangkontakten.

Den kemiske variation på tværs af gangen vil kunne tolkes som et resultat af, at det først intruderede magma har varet 
mere differentieret end senere tilkommet magma, der så har undergået en svag differentiation mod gangmidten (tydeligst eksemplifieret af $\mathrm{SiO}_{2}$ i fig. 5). Variationen i $\mathrm{K}_{2} \mathrm{O}$ stemmer imidlertid ikke med en sådan antagelse, og tilstedeværelsen af den $1 \mathrm{~cm}$ tykke omdannelseszone af albit langs kontakten kan også tyde på, at variationerne på tværs af gangen er resultatet af autometasomatiske omdannelser, vasentligst i form af albitisering. Tabel 11 viser, at der er ret stor overensstemmelse mellem kontaktprøverne og prøverne fra gangmidten, hvis man til pr $\varnothing$ verne fra gangmidten adderer $20 \%$ albit.

Såvel retningen af Bjergebakkegangen som dens mineralogiske og kemiske sammensætning svarer nøje til kullaiterne i Skåne, men medens alle gangene $i$ det bornholmske grundfjeld anses for at være prækambriske, så anses kullaiterne for at være postsilure.

Foreløbige aldersbestemmelser af Poul Martin Holm, Institut for Petrologi, giver kullaiter fra Skåne en højere alder end Bjergebakkegangen, men aldersbestemmelserne anses ikke for endelige og yderligere aldersbestemmelser, der også omfatter de bornholmske doleriter, er under udførelse.

\section{References}

Bayliss, P. 1975: Nomenclature of the trioctahedral chlorites. Can. Mineral. 13, 178-180.

Cathelineau, M. \& Nieva, D. 1985: A chlorite solid solution geothermometer, the Los Azufres (Mexico) geothermal system. Contrib. Mineral. Petrol. 91, 235-244.

Finger, L.W. 1972: The uncertainty in the calculated ferric iron content of a microprobe analysis. Carnegie Inst. Wash. Yearb. 71, 600-603.

Foster, M.D. 1962: Interpretation of the composition and a classification of the chlorites. U.S. Geol. Surv. Prof. Pap. 414-A, 1-33.

Ganapathy, R. \& Anders, E. 1974: Bulk composition of the Moon and Earth estimated from meteorites. Proc. Lunar Sci. Conf. 5, 1181-1206.
Hawthorne, F.C. 1981: Crystal chemistry of the amphiboles, 1-102 In Veblen, D.R. (ed.) Amphiboles and other hydrous pyriboles-mineralogy, Reviews in Mineralogy, vol. 9A. Min. Soc. Amer.

Hennig, A. 1899: Kullens kristalliniska bjergarter II. Lunds Univ. drsskrift 35, Afd. 2, Nr. 5, 1-34.

Hjelmqvist, S. 1930: Kullait von Dalby. Geologiska Föreningens $i$ Stockholm Förhandlinger 52, H.2, 247-268.

Johannsen, A. 1937: A descriptive petrography of the igneous rocks, vol III, $360 \mathrm{pp}$. University of Chicago Press, Chicago, Illinois.

Kalsbeek, F. \& Taylor, P.N. 1985: Age and origin of early Proterozoic dolerite dykes in South-West Greenland. Contrib. Mineral. Petrol. 89, 307-316.

Kalsbeek, F. \& Taylor, P.N. 1986: Chemical and isotopic homogeneity of a $400 \mathrm{~km}$ long basic dyke in central West Greenland. Contrib. Mineral. Petrol. 93, 439-448.

Le Bas, M.J., Le Maitre, R.W., Streckeisen, A. \& Zanettin, B. 1986: A chemical classification of volcanic rocks based on the total alkali-silica diagram. Journal of Petrology 27, 745-750.

Norrish, K. \& Chappell, B.W. 1977: X-ray fluorescence spectrometry 201-272 In Zussman, J. (ed.) Physical methods in determinative mineralogy, 2.ed. Academic Press, London.

Robinson, P., Spear, F.S., Schumacher, J.C., Laird, J., Klein, C., Evans, B.W. \& Doolan, B.L. 1982: Phase relations of metamorphic amphiboles: natural occurrence and theory 1-227 In Veblen, D.R. \& Ribbe, P.H. (eds) Reviews in Mineralogy 9 B, Amphiboles: petrology and experimental phase relations. Mineralogical Society of America.

Ross, M.E. 1983: Chemical and mineralogic variations within four dikes of the Columbia River basalt group, southeastern Columbia Plateau. Geol. Soc. Amer. Bull. 94, 11171126.

Wood, D.A., Joron, J-L., Treuil, M., Norry, M. \& Tarney, J. 1979: Elemental and $\mathrm{Sr}$ isotope variations in basic lavas from Iceland and the surrounding ocean floor. Contrib. Mineral. Petrol. 70, 319-339. 